\title{
B2B/Endüstriyel Pazarlar İçin Anahtar Müşteri Yönetimine İlişkin Müşteri Yaşam Boyu Değerinin Hesaplanmasında Muhasebe ve Pazarlamanın Rolü
}

\author{
Vedat Ekergil $^{\mathrm{a}}$
}

Nezihe Figen Ersoy ${ }^{b}$

\begin{abstract}
Öz: Müşteri yaşam boyu değeri, uzun süredir birçok akademisyenin ve pazarlama yöneticisinin üzerinde durduğu bir kavramdır. Müşteri yaşam boyu değerinin temel amacı, işletme için müşterilerin önem derecelerini belirlemektir. işletme hangi müşterisi için ne kadar yatrım yapmalı, hangi müşterisi için ne tür bir pazarlama stratejisini tercih etmeli ve hangi kampanyaları düzenlemeli gibi soruların cevabı müşterilerin yaşam boyu değerlerinin hesaplanmasıyla belirlenebilmektedir. Müşteri yaşam boyu değeri hesaplanması için birçok akademisyen çeşitli modeller öne sürmüşlerdir. Fakat hangi tip modellerin daha üstün sonuçlar verdiğine dair ilgili alan yazında bir sonuç bulunmamaktadır. Bu makalenin amacı, bazı modelleri inceleyerek, yapılan hesaplamalar sonucunda, aynı veri tabanı ve değişkenlerin kullanımıyla seçilen sektöre uygun görülen müşteriler arasında bir bölümleme yapmaktır.
\end{abstract}

Anahtar Sözcükler: Müşteri, Müşteri Yaşam Boyu değeri, Anahtar Müşteri, Pazarlama Muhasebesi, Müşteri Bölümleme

JEL Sınıflandırması: M31, M40, M41

\section{The Role of Accounting and Marketıng in Calculating Customer Lifetime Value on Key Account Management in B2B/Industrial Markets}

Abstract: Customer lifetime value is a concept which many academics and in practice many marketing managers are working on for a long time. The main objective of the customer lifetime value is to determine the degree of importance of customers for the company. Answers of questions such as; how much the company should invest to which customer, what kind of marketing strategies should it prefer for which customer and which campaigns should it organize; can be determine by calculating the customer lifetime value. Many academics have proposed several models for the calculation of Customer lifetime value. But there is not any judgement in the literature about which types of models provide superior results. The purpose of this study is to create a cluster between customers with examining some of the models deemed suitable for the selected sector in the literature, result of the calculations, using the same database and variables.

Keywords: Customer, Customer Lifetime Value, Key Account, Accounting of Marketing, Segmentation

JEL Classification: M31, M40, M41

\footnotetext{
aAssoc. Prof., PhD., Anadolu University, Open Educatıon Faculty, Eskisehir, Turkiye, vekergil@anadolu.edu.tr (Principal Author/Başlıca Yazar)

${ }^{b}$ Assoc. Prof., PhD., Anadolu University, Faculty of Economics and Administrative Sciences, Eskisehir, Turkiye, nfersoy@anadolu.edu.tr
} 


\section{Giriş}

Teknolojik ilerlemeler ve yoğun ancak işbirliğine yönelik rekabet ile tanımlanan günümüz pazar çevresinde müşterileri elde tutma ve müşteri ilişkilerini koruma, işletmelerin başarısında çok önemlidir. Özellikle farklılık yaratmanın işletme başarısındaki temel unsur olduğunun anlaşılması ancak buna rağmen farklııı̆ın uzun süre korunamaması, işletmelerin müşteri odaklı düşüncelerinin yapısını da değiştirmiş; müşteri odaklılığını başlangıçta kârlııı̆a dayalı bir müşteri yönetimi ile tanımlayan işletmeler artık kârııı̆ın ötesinde yaşam boyu değer kavramı üzerinde odaklanmışlardır. Dolayısıyla müşteri ilişkileri yönetimini daha etkili yapabilmek hatta anahtar müşterilerle ilişkileri daha doğru ve etkili kılabilmek için, müşteri davranışlarını ve kârııı̆ını anlamak ve bu kavramlarla müşterinin yaşam boyu değeri arasında ilişki kurmak, bu bilgileri mevcut ekonomik yapıda rekabetçi avantaj yaratmak için kullanmak önemlidir.

Pazarlama yöneticileri, kârları etkileyen fiyatlama, dağıtım, reklâm harcamaları, satış gücü tahsisleri, ürün hattında yapılan değişiklikler ve diğer birçok faktör hakkında kararlar alırlar. Bilgi, bu kararların temelini oluşturur ve doğru bilgi daha iyi kararların alınmasını sağlar. İşletme içinde bu bilgilerin başlıca kaynağı yönetim bilgi sistemidir. Yönetim bilgi sistemini oluşturan alt sistemlerden biri olan muhasebe bilgi sistemi ise pazarlamacıların müşteri ilişkilerini yönetmede kullanacakları ana bilgi üreticilerinden biridir. Ancak muhasebenin birincil odağı, yatırımcılar, bankalar ve düzenleyici kuruluşlar gibi dış gruplara hizmet etmektir. Pazarlama, finans ve üretim gibi iç gruplara hizmet etmek ise, muhasebenin ikincil odağını oluşturmaktadır (Özdemir ve Kaygusuz, 2009:90; Stevenson vd., 1993:40). Bu aşamada özellikle konuyla ilintili olarak pazarlama muhasebesi üzerinde odaklanmak gerekir. Pazarlama muhasebesi, müşteri yaşam boyu değerinin hesaplanmasında son derece önemli bir role sahiptir.

\section{Yöntem}

Bu çalışma bir tanımlayıcı araştırmadır. Bilindiği gibi tanımlayııı araştırmalar, araştırma probleminin özelliklerini ve oluş sıklığını belirleme, problem üzerinde etkili olan değişkenleri ve bu değişkenlerin önem derecelerini ortaya çıkarmak, problemin ortaya çıkış biçimini tahmin etmek ve değişkenler arasındaki ilişkiyi belirleyerek genellemelere varmak için yapılır. Bu araştırmaların amacı, nedensel bir ilişki kurarak genellemelere varmak, sistemleştirip sınıflandırmak ve tahminlerde bulunmaktır (i̇slamoğlu, 2009:34).

Müşteri yaşam boyu değeri hesaplanması için birçok model öne sürülmüştür. Fakat hangi tip modellerin daha üstün sonuçlar verdiğine dair ilgili alan yazında kesin bir sonuç bulunmamaktadır. Bu çalışmada araştırma probleminin belirlenmesinde bu başlangıç noktasından hareket edilmiştir. Araştırma problemi, anahtar müşteri yönetimi sürecinde müşteri yaşam boyu değerinin hesaplanmasında öne sürülen ve yaygın kabul görmüş modelleri inceleyerek, yapılan hesaplamalar sonucunda, aynı veri tabanı ve değişkenlerin kullanımıyla seçilen sektöre uygun görülen müşterileri bölümleyerek bölümler arasında yöntemlere göre fark bulunup bulunmadığıdır. Araştırma problemine bağlı olarak bu farkın ortaya konulması, çalışmanın amacını oluşturmaktadır. Çalışmanın temel varsayımı, örnek şirketten alınan verilerin tümüyle gerçek ve doğru olduğudur.

\subsection{Araştırmanın Evreni ve Veri Toplam Aracı}

Müşteri Yaşam Boyu Değerinin hesaplanmasında bir işletmenin çok yıllık veri setinden yararlanılmaktadır. $\mathrm{Bu}$ nedenle yapılan çalışmalarda genellikle kurgu veri seti üzerinden gerçekleştirilmektedir. Bu çalışma, isminin açıklanmasını istemeyen bir $(A)$ işletmesinden gerçek veri setine dayalı olarak gerçekleştirilmektedir. (A) işletmesi, elektrik ürünleri tedarikçisi olan ve B2B/Endüstriyel müşterilere hitap eden orta ölçekli bir işletmedir.

Araştırmaya kaynak oluşturacak veriler (A) İşletmesinin muhasebe, bilgi işlem ve pazarlama bölümlerinden elde edilmiştir. İşletmenin 56 adet tüzel kişi niteliği olan müşterinin 2013, 2014 ve 2015 dönemlerinin 11.302 satışa bağlı muhasebe kayıtları incelenerek veri seti tarafimızca hazırlanmıştır. 


\subsection{Verilerin Analizi}

Çalışmanın temelini oluşturan verilerin hangi kaynaklarda olduğunun tespitinden sonra verilerin ilgili kaynaklardan toplanması, verilerin birleştirilmesi ve analize uygun olacak şekilde verinin dönüştürülmesi aşamaları veri hazırlamayı oluşturmaktadır. Bu yönde, (A) işletmesinin muhasebe ile pazarlama departmanından alınan veriler ile bilgi işlem departmanından alınan ilgili yıllara ilişkin veriler bir araya getirilerek, müşterilere ilişkin bir veri seti oluşturulmuştur. Bu veri seti daha sonra $(A)$ işletmesinin hem muhasebe hem de pazarlama departman yöneticileri tarafindan da kontrol edilmiş, geçerlik ve güvenirlik sağlanmıştır. (A) İşletmesinden alınan verilere bağlı olarak oluşan yeni veri seti Excel 2013 programı kullanılarak farklı müşteri yaşam boyu değeri hesaplama modellerine göre analiz edilmiştir. Bu analizler sonunda müşteri her bir modele göre oluşan müşteri yaşam boyu değeri karşılaştirılarak ortalama rakamlara ulaşılmış ve bu rakamlara göre müşteri bölümleri tanımlanmıştır.

\section{Pazarlama ve Muhasebe: Pazarlama Muhasebesi}

İş Pazarlama kararlarının, çeşitli kaynaklardan sağlanan güvenilir bilgilerle desteklenmesi gerekmektedir. Özellikle gelecekteki faaliyetlerin planlanması ve kontrolünde çoğu durumda işletmenin muhasebe bölümünden sağlanan bilgilerden yararlanılmaktadır. Bir kararın kalitesi, soruna uygun biçimde yönelmeye bağlıdır. Bu nedenle kaliteli karar almayı kolaylaştırması bakımından pazarlama bilgilerinin muhasebe bilgileriyle desteklenmesi gerekmektedir. Bu yönde Ceran ve İnal (2004) pazarlama muhasebesi kavramını öne sürmektedirler. Onlara göre, bütünleşik bir kavram olarak pazarlama muhasebesi, "pazarlamayla ilgili bilgilerin toplanması ve tüm çalışanlara iletilmesidir". Satı̧ denetiminin temel bir aracı olarak pazarlama, satı̧ ve dağıtım maliyetleri; pazarlama fonksiyonu alanı üzerinde sınırlı kalmakta ve pazarlama denetiminin bir aracı biçiminde fonksiyonlar üstü bir anlayış olarak görülmektedir (Ceran ve İnal, 2004:66; Köhler, 1989: 118).

Müşteri Yaşam Boyu Değerinin hesaplanmasında bu anlamda pazarlama muhasebesi son derece önemlidir. Doğru stratejinin geliştirilmesinde özellikle muhasebe bilgilerinin önemi tartş̧ımazdır. Dolayısıyla Müşteri İlişkileri Yönetimin temelinde pazarlama muhasebesi bulunmaktadır.

\section{Müşteri Yaşam Boyu Değeri}

Pazarlamanın aslında her zaman en önemli odak noktası müşteridir. Bilindiği üzere niteliği ne olursa olsun ve ister tüketici isterse B2B/Endüstriyel müşterilere hizmet etsin işletmelerin tümü için müşteriler en değerli varlıktır ve temel var olma nedenidir (Edvardsson vd., 1994:116; Özdemir Özkan, 2007: 29; Peelen ve Beltman, 2013: 15; Ersoy, 2015:6). Özellikle B2B/Endüstriyel pazarda işletmeler müşterileriyle olan ilişkiler, pazar başarısının temelini oluşturmaktadır. Öyle ki, pazarın kendine has özelliklerinden ötürü müşterinin nitelikleri de değişmekte, karşılıklı işbirliğine dayanan, daha uzman ve daha bilinçli ve tüketiciyle kurulan ilişkiye göre daha talepkâr olan bir işletme-müşteri ilişkisiyle karşılaşılmaktadır. Bu durum, bir varlık olarak müşterinin değerini arttırmaktadır. Özellikle bu pazarda daha büyük hacimde ve değerde yapılan alışverişler söz konusu olduğundan müşteriyle olan ilişkiyi doğru yönetmek, kurumsal kaynak planlamasındaki CRM uygulamalarının ötesine geçmektedir. Dolaysıyla doğru müşteriyle doğru işi yapmak, bunu sürdürülebilir ve geliştirilebilir hale dönüştürmek işletmenin varlığını sürdürmesinde ve pazar başarısını yakalamasında temel kritik faktördür.

\subsection{Müşteri Kârlılığı, Anahtar Müşteri ve Müşteri Yaşam Boyu Değeri Kavramları}

Müşteri kârlılığı analizleri, her bir müşteri veya müşteri bölümüne göre gelirlerin, maliyetlerin ve kârların belirlenmesini içerir. (Özdemir ve Kaygusuz, 2009:91) Müşteri kârlılığı, aslında müşteriyle kurulan ilişkinin o anda işletmeye ne kadar katkıda bulunduğunu gösterir. Bu oran mevcut durumu değerlendirmek için önemlidir ancak müşteriyle olan ilişkiyi tam olarak değerlendirmek için yeterli değildir. Dolayısıyla hangi müşteriyle nasıl bir ilişki kurması gerektiğine dair işletme için bir rehber niteliği görmez. 
Ancak, işletmenin tüm müşterilerini elde tutması ve tüm müşterilerine eşit davranması mümkün değildir. Bu hem müşterilerin tatmin/tatminsizlik düzeyini etkiler hem de işletmenin gereksiz maliyetlerle karşılaşarak yatırımın geri dönüş oranının düşmesine neden olur. Bu yönde işletmelerin uygulaması gereken stratejinin temelinde müşterilerin birbirinden ayrılması bulunmaktadır. Bir başka ifadeyle, işletmenin müşterilerini işletmeye olan katkılarına, yatırım geri dönüş oranlarına ve kurulan ilişkinin kalitesine göre gruplara bölmesi gerekir. Her bir gruba uygun strateji uygulandığında işletmenin yatırım geri dönüş oranını maksimize etmesi mümkün olur. Böylelikle hangi müşteri için ne kadar maliyete katlanmak gerektiği belli olduğundan işletmenin kârlı olan müşterisini daha düşük kârlı hatta kârsız müşteriden ayırması işletmenin yararına olur. Dolayısıyla, işletmenin pazarlama faaliyetlerinde kârlı grup ya da gruplara yönelmesi ile elde tutulan müşterilerin işletme kârlılı̆ı üzerindeki etkisi işletme yöneticileri için önemlidir. Bu yönde işletmenin iki temel fonksiyonunun (pazarlama ve muhasebe) işbirliği, işletmelerin doğru kararı vermelerinde ve müşteri yönetiminde doğru stratejiler geliştirmesinde etkili olmaktadır.

Geleneksel işletme yönetimi anlayışında, işletmenin gelirlerinin $\% 80$ 'ini ürünlerin \%20'sinin sağladığını belirten Pareto yasası (80-20 ilkesi), genel kabul gören ve oldukça sık kullanılan bir kavramdır. 1980 'lerle birlikte müşteri odaklılık, müşteri tatmini gibi kavramların artan önemi işletmeleri, özellikle pazarlamacıları ürünler yerine müşterilerine odaklanma zorunda bırakmıştır (Koch,1999:114-120). Işsletmelerin gelişen bilişim teknolojilerinin de etkisiyle sahip oldukları karmaşık bilgi sistemleri ve bilgi yönetimi becerileri Pareto yasasının müşterilere de uyarlanabilmesinde en önemli yardımcı rolünü üstlenerek, müşterilerin daha yakından izlenmesine olanak tanımıştır. (Özdemir Özkan, 2007:29)

Kırım'a göre (2001:163), müşteriler iki açıdan farklıık gösterirler:

- Her müşterinin değeri işletme için farklıdır.

- Her müşterinin işletmeden beklentileri farklıdır.

Bu temel farklııklara müşteriyi yönetmek, işletme başarısı için önemlidir. Bu bağlamda işletmeler için ilişkisel pazarlama anlayışı ön plana çıkar. İlişkisel pazarlama anlayışına ilişkin literatürde önemli/değerli müşteri kavramı, anahtar müşteri kavramı ile örtüşür. Millman ve Wilson (1995:9) kavramı şöyle tanımlar:

"satıcı işletme için stratejik önem taşıyan müşteri".

Özdemir Özkan'a göre (2007:31), anahtar müşteri ilişkisinde genellikle geleneksel satş yönetiminin içeriğinden daha geniş bir odak söz konusudur. Geleneksel satı̧ yönetimi kârlılı̆ın üzerine odaklanırken, anahtar müşteri ilişkileri daha yakın ilişkiler, daha düşük toplam maliyet, satıcının hizmet maliyetinin, müşterinin kazanılması ve elde tutulması ile ilgili işlem maliyetlerinin düşürülmesi gibi odakları söz konusudur. Bu yönde anahtar müşteri ilişkileri genel olarak Cannon ve Nayandas'ın (2000: 410) belirttiği gibi bazı özelliklere sahiptir:

- Uzun süreli olması

- Karşılıklı bağlılık içermesi

- İki tarafinda yüksek düzeyde talep taahhüdünde bulunması

Dolayısıyla bu müşterileri kazanmanın, elde tutmanın ve yönetmek son derece stratejik kararlar içermektedir. Bu kararların temelinde müşteri yaşam boyu değeri bulunur. Müşteri yaşam boyu değerinin hesaplanmasında da özellikle muhasebe verilerinin önemini ayrıca belirtmek gerekir.

Schneider/Sağlam'a göre, (2007:32-37) günümüzün yeni rekabet koşullarında müşterinin işletmenin temel varlığı haline dönüştüğü bu süreç içinde işletmeler için önemli olan; ellerindeki tüm kaynakların doğru ve verimli bir şekilde müşterileri için kullanabilmeleridir. Ne yazık ki, işletmelerin kıt kaynaklara sahip olmaları tüm müşterilerin aynı derecede ilgi görmesini engellemektedir. Benzer şekilde müşterilerin işletmeyle kurdukları ilişki ve alışveriş yoğunluğu da birbirlerinden farklıdır. Bu noktada, sahip olunan müşteriler içinde işletme için hangilerinin ne kadar değerli olduğunun belirlenmesi, kimin işletme için kârlı müşteri statüsünde olduğunun tanımlanması, kimin portföyündeki varlığının kârdan çok zarar getirdiğinin belirlenmesi 
gerekmektedir. Bu önemli görevlerin müşterilerin uzun dönemli değerlerini göz önünde bulunduran müşteri yaşam boyu değeri analizleri ile yapılabilmesi, kavramı işletmelerin gündemine getirmiştir. (Yapraklı ve Keser, 2008:187)

Müşteri yaşam boyu değeri, işletmenin müşterilerinin satın alma davranışı üzerinde pazarlamanın etkisini ortaya koyar ve kavram, hedeflenen pazarlama faaliyetleri için değerli bir yatırım ölçüsüdür. Bu noktada özellikle işletmelerin pazarlama yatırımlarından söz etmek gerekir. İşletmeler, devamlılıklarını sağlamak için yeni müşteri kazanmak, bu müşterileri elde tutmak ve korumak zorundadırlar. Günümüz koşulları içinde müşteriler işletmenin en önemli kıymetleri haline dönüşmüştür. Müşterilerle kurulan ilişkiler ve bu ilişkilerin yönetimi bu noktada önemlidir. Dolayısıyla bu kıymeti oluşturabilmek, marka değeri yaratmak için işletmenin kaynaklarını kullanması ancak bu kaynakların maksimum geri dönüşünü sağlaması gerekir. Bu yönde yapılan pazarlama yatırımlarını kontrol etmede Müşteri yaşam boyu değeri son derece önemli bir araç olarak ifade edilmektedir. (Perrson ve Ryals,2010:420)

Zinkhan ve Verbrugge (2000:145) müşteri yaşam boyu değerini tanımlamada temel odak, işletmenin yaptığı pazarlama yatırımları sonucu oluşan müşterileriyle kurduğu ilişkilerden sağlanan kârların net bugünkü değerleridir. Bu değer, her bir müşteri için ayrı ayrı hesaplanabildiği gibi müşteri grupları için de ortalama olarak da hesaplanabilir. Müşteri yaşam boyu değeri, Zinkhan ve Verbrugge (2000)'un tanımı açısından kavramı irdeleme sırasında unutulmaması gereken temel nokta, müşteri yaşam boyu değerinin asla müşteri kârı ile eşit bir kavram olmadığıdır. Zinkhan ve Verbrugge (2000)'un yaptı̆̆ tanımı destekleyen benzer pek çok tanım bulunmaktadır. Örneğin, Berger ve Nasr'da (1998:18-19) müşteri yaşam boyu değerini bir işletmenin müşterisinden elde etmeyi umduğu gelirlerden o müşteriyi kazanmak için katlandığı maliyetlerin bir başka ifadeyle yaptı̆ı pazarlama yatırımlarının çıkarılması sonucu artan kısım olarak ele almaktadır. Öyle ki, onlara göre işletmeler için MYBD’ni hesaplamak son derece kolay bir uygulamadır(Berger ve Nasr, 1998:18).

Kumar ve Shah (2004)'a göre, müşteri yaşam boyu değeri, şimdiki zamandan gelecekte belirlenen bir zamana kadar müşteri ilişkileri sonucu elde edilen kâr beklentisini ölçmedir. (Selvi, 2007:141)

Kumar (2008)'de kavramı yeniden tanımlamıştır. Ona göre, müşteri yaşam boyu değeri gelecekteki nakit artı̧larının bugünkü değeridir; müşteri kârı ise, belli bir zaman periyodunda satış gelirlerinden maliyetin çıkarılması ile ortaya çıkan değerdir. Kumar müşteri kârı ve yaşam boyu değeri kavramlarını tanımlayarak her iki temel kavram arasındaki farkı ortaya koymakta ve Zinkhan ve Verbrugge (2000: 143-148)'u desteklemektedir.

MYBD'ni sadece müşterilere yapılacak özellikle tutundurma maliyetlerindeki tasarruf olarak bakmamak gerekir. Elbette yeni müşteri kazanmanın maliyeti her zaman mevcut müşteriyi korumanın maliyetinden daha fazladır. Ancak burada konuya sadece tutundurma maliyetlerindeki tasarruf olarak yaklaşmak konunun önemini gözden kaçırmaya neden olacaktır. MYBD ile işletme müşterilerle doğru ilişki kurma ve gelecekteki kârlılığı yönetme açısından elindeki kısıtlı tüm kaynakları maksimum verimlilikte kullanmayı başarır. Böylelikle işletmenin temel amacı olan kârlılığının artmasında işletmenin mevcut kıt kaynaklarının etkinliğini/verimliliğini yükseltir. Pazarlamada özellikle de müşteri ilişkileri yönetiminde önemli bir ölçüm olan müşteri yaşam boyu değeri, müşterilerin sadece geçmişte satın aldıkları ürün ve hizmet hatlarına odaklanılması yerine, müşterilerin işletme ile olan tüm yaşam boyu ilişkilerine odaklanılarak müşterilerin uzun dönem kârlılığının değerlendirilmesidir. (Yapraklı ve Keser, 2008:187'den Cokins, 2006; Wu vd., 2005;Kandell, 2000) Bu yönüyle özellikle "müşteriyle kurulan ilişkilerin" bir sermaye veya işletme varlığı haline dönüştüğü düşünüldüğünde müşteri yaşam boyu değeri , işletmenin günümüzdeki en önemli kaynağını doğru, verimli ve sürdürülebilir biçimde yönetmesini olanaklı kılan bir yönetim aracına dönüşür. Web 3.0'dan Web 4.0'a doğru geçerken bilgi teknolojilerinin gelişimi söz konusu yönetsel aracın işletme ve müşteri ilişkileri yönetimindeki kullanımını artırmıştır.

Müşteri yaşam boyu değeri, karar verici için müşterinin değerine ilişkin bir ölçüdür. İşletmenin mevcut müşterilerinin işletme kârlılığına yaptıkları katkıyı belirlemede söz konusu ölçü, belirsizlik ortamında doğru karar vermek zorunda olan karar vericilere kolaylık sağlar. Müşteri yaşam boyu değeri ayrıca, müşterilerin yaşam boyu kârlarını maksimize etmek ve işletmeyle kurdukları ilişkilerde yaşam eğrisinin 
süresini uzatmak için müşteri odaklı stratejileri tasarlama ve uygulamada işletme için bir temel sağlar. Diğer bir ifadeyle, Müşteri yaşam boyu değeri işletmenin tüm müşterilere eşit davranmasından ziyade kâra olan katkılarına göre her bir müşteriye farklı (ayrı) davranmasını olanaklı kılar. Böylece işletmenin müşteri ilişkileri yönetimi sırasında katlandığı pazarlama yatırımlarının işletmeye geri dönüş oranını yükseltir. Bir başka değişle, Müşteri yaşam boyu değeri ölçüsü kullanılarak müşterilerin işletme kârlılığına katkıları oranında pazarlama yatıımı yapılarak, işletme kaynaklarııı verimli ve doğru kullanımı sağlanmış olur. Özellikle alıcılar pazarında rekabet gösteren ve işletme verimliliğinin düşük olduğu pazarda, kaynakların bu yöndeki doğru kullanımı verimlilik oranını yükselterek işletmenin rekabet gücünü yükseltir. Müşteri yaşam boyu değerinin hesaplanması yatırımların pozitif oranda geri dönüşüne ulaşmak için kazanılmış müşterilere ne kadar yatıım yapılması gerektiğini de işletmeye gösterir. İşletme daha önce de ifade edildiği gibi, sınırlı kaynaklara sahiptir ve ideal olarak, bu sınırlı kaynaklarını işletmeye maksimum geri dönüş getiren müşterilere kullanmak istemektedir. Bu, sadece müşterinin işletmeyle bağıntılı yaşam dönemi boyunca ortaya çıkan kümülatif nakit akışını ya da onların yaşam boyu değerlerini bulmakla mümkündür (Kumar, 2008:4). İşletme, müşterilerinin yaşam boyu değerlerini hesapladığında, pazarlama yatırımlarının maksimum geri dönüşü hedefine ulaşmada sınırlı kaynaklarını optimal olarak dağıtır. Müşteri yaşam boyu değeri çerçevesi, ayrıca satın alma sıklığı analizi ve müşteri odaklı iletişim stratejilerini de temel olarak alır. Müşteri yaşam boyu değeri ayrıca müşteri odaklı stratejiyi yerleştirmeye başlayan (uyum göstermeye-adapte olmaya çalışan) işletmede uygulanmakta olan pazarlama faaliyetlerinde de kaynakların tahsis edilmesinde bir ölçek olarak da kabul edilir (Berger ve Nasr, 1998:16).

\subsection{Müşteri Yaşam Boyu Değerinin Hesaplanması İle İlgili Genel Bilgiler}

Stahl, Matzler ve Hinterhuber'e (2003:269) göre, müşteri yaşam boyu değerinin hesaplanması ve uygulanması pazarlama açısından özellikle de uzun dönemli kârlı müşteri ilişkilerinin geliştirilmesi ve sürdürülmesi noktasında son derece önemlidir. Müşteri Yaşam boyu değerine ilişkin hesaplamalarda müşterinin tüm yaşam süresine odaklanılarak uzun dönemli değeri göz önünde bulundurulur. Müşterinin yaşam süresi, işletme ile ilişkide bulunduğu dönem ile tanımlanır. (Hwang vd., 2004:183) Bu son derece önemlidir ve belki de müşteri yaşam boyu değerinin hesaplanmasındaki en büyük eksikliklerden biridir.

Müşteri yaşam boyu değerinin hesaplanması birçok şekilde yapılabilmektedir. Hesaplamanın firmanın gerçekleştirdiği iş uygulamalarına bağlı olarak farklı yaklaşımlar gerektirmesi söz konusudur (Kumar vd., 2004: 7). Başka bir ifadeyle, MBYD'ye ilişkin hesaplamalar sektöre, işletmeye, işletmenin içinde bulunduğu bölgeye, hitap edilen müşteri bölümüne göre farklılık göstermektedir. Reinartz ve Kumar (2000) tarafindan MYBD'nin tek bir model ile ele alınamayacağı, işletmelerin içinde bulundukları sektör ve diğer değişkenlere göre farklı modellere intiyaç duyabileceği ifade edilmiştir.

Günümüzün yanal rekabet koşullarında özellikle B2B_endüstriyel pazarlarda ve tedarik zinciri içinde müşteriler işletmenin en önemli varlıkları haline dönüşmüştür. Bunun temel nedeni büyüme oranı düşen ekonomi içinde artan teknolojik imkânlar ve son kullanıcıları etkileyen trendlerdeki hızlı değişime şirketinizin üretmek zorunda olduğu esnek ve hızlı karşıııtır. Eğer değişen koşullara hızlı yanıt veremez ve müşterilerinizi doğru yönetemezseniz tehditlere açık hale gelirsiniz. Bu da bir şirket için en kötü senaryolardan biridir. Müşterilerle kurulan ilişkiler ve bu ilişkilerin yönetimi bu noktada önemlidir. Dolayısıyla bu varlıkların oluşturulmasında marka değerini yaratmak için kullanılan işletme kaynaklarının işletmeyle en üst düzeyde geri dönüşünü (ROI) sağlayacak şekilde tasarlanması gerekmektedir. Bu yönde yapılan pazarlama yatırımlarını kontrol etmede müşteri yaşam boyu değeri son derece önemli bir araç olarak ifade edilmektedir. Buna ilişkin bir yol haritası Şekil 1'de verilmektedir.

İşletmelerin karşılaştı̆̆ı stratejik sorunlardan biri müşteri yaşam boyu değerinin ölçümüdür. Konu ile ilgili yapılan birçok çalışma, müşteri verilerinin kullanıldı̆̆ı pek çok ölçme yöntemi olduğunu göstermektedir. $\mathrm{Bu}$ yöntemler arasında yaygın olarak, zaman içinde müşteriden gelen net gelirin cari değeri hesaplanmaktadır. Burada özellikle brüt gelirden müşteriyi kazanmak ve elde etmek için işletme tarafindan katlanılan maliyetler düşüldükten sonraki net gelir temel olarak kabul edilmektedir. 
Hesaplamada müşterinin gelecekteki davranışları hakkında işletmeye ipucu veren müşteri davranışlarının detaylı bir şekilde anlaşıması önemli bir konudur. Hesaplama, şimdiki ve düşünülen ileriki zamana ait tahmin edilen müşteri gelir akımının net değerine ve bu gelir akımına karşı şimdiki ve tahmin edilen gelecekteki harcamalara dayanmaktadır (Alagöz, 2003: 49). Bu tahminlerin başarılı bir şekilde yapılması için müşteri ilişkisi ile ilgili tüm gelir ve maliyetlerin detaylı bir şekilde analizinin ve değerlendirilmesinin yapılması gereklidir (Stahl vd., 2003:269; Tarhan, 2016:33-35).

\section{Şekil 1. MYBD’ni Belirlemeye Yönelik Yol Haritası}

\begin{tabular}{|c|c|c|c|c|c|}
\hline \multicolumn{3}{|c|}{ I. Aşama } & \multicolumn{3}{|c|}{ II. Aşama } \\
\hline $\begin{array}{c}\text { İş } \\
\text { Çevresi } \\
\text { Analizi }\end{array}$ & $\begin{array}{c}\text { Veri } \\
\text { Toplama }\end{array}$ & $\begin{array}{c}\text { Veri } \\
\text { ilişkilendirme }\end{array}$ & $\begin{array}{c}\text { Müşteri } \\
\text { Değeri } \\
\text { Hesaplama }\end{array}$ & $\begin{array}{c}\text { Müşteri } \\
\text { Bölümleri } \\
\text { Tanımlama }\end{array}$ & $\begin{array}{l}\text { Müşteri } \\
\text { Bölümleme } \\
\text { Analizi } \\
\text { Yapma }\end{array}$ \\
\hline \multicolumn{3}{|c|}{$\begin{array}{l}\text { Şirket İçi Veriler: } \\
\text { - Müşteri Profili } \\
\text { - Davranışsal Veriler } \\
\text { - Araştırma ve İnceleme Raporları } \\
\text { Şirket Dışı Veriler: } \\
\text { - Yeni müşteri kazanma maliyeti } \\
\text { - Tedarik zinciri işbirliği maliyeti }\end{array}$} & \multicolumn{3}{|c|}{$\begin{array}{l}\text { - Mevcut Değer } \\
\text { - Potansiyel Değer } \\
\text { - Sadakat }\end{array}$} \\
\hline \multicolumn{6}{|l|}{$\mathbf{4}$} \\
\hline & \multicolumn{4}{|c|}{ III. Aşama } & \multirow{3}{*}{4} \\
\hline & $\begin{array}{r}\text { Pazarlam } \\
\text { Olı }\end{array}$ & $\begin{array}{l}\text { na Stratejisini } \\
\text { uşturma }\end{array}$ & \multicolumn{2}{|c|}{ Müşteri Analizi } & \\
\hline & \multicolumn{4}{|c|}{$\begin{array}{l}\text { - Her bir müşteri grubunun özelliklerini tanımlama } \\
\text { - Müşteri özelliklerini ortaya koyma }\end{array}$} & \\
\hline
\end{tabular}

MYBD hesaplamalarında maliyetlerin doğru bir şekilde ölçülmesi en önemli konulardan birisidir. Müşterilerden elde edilen gelirler uygun bir faturalama sistemi ile elde belirlenebilirken, maliyet bilgisi toplu bir şekilde elde edilmekte ve bireysel müşterilerle veya müşteri gruplarılla ilişkilendirilmeden önce iyi bir şekilde analiz edilmesi ve ayrıştırılması gereklidir. Dolaylı maliyetlerin bölünmesi ve dağıtılması özellikle daha zor olmaktadır (Gurau ve Ranchhod, 2002:209).

MYBD hesaplamasında, müşterilerin sadece satın alma miktarı olarak işletmeye kazandırdıkları değil, aynı zamanda sadık bir müşteri olmasıyla elde edilen tüm faydalar dikkate alınmaktadır (Tekel, 2006:73). Bütün harcama detaylarının da göz önünde bulundurulmasıyla birlikte hesaplama genellikle bireysel müşteri temelleri üzerine yapılmaktadır. Bu bilgiler daha sonra müşterinin gelecekteki gelir akımlarını belirlemek için bir senaryo oluşturmada kullanılmaktadır (Alagöz, 2003:49).

\subsection{Müşteri Yaşam Boyu Değeri Hesaplama Süreci}

MYBD’nin hesaplanmasında net katkı payı önemli bir unsurdur. Net katkı payının belirlenmesi şöyledir:

Brüt Katkı Payı $=$ Net Satışlar - Değişken Satılan Malların Maliyeti

Net Katkı Payı = Brüt Katkı Payı - Değişken Satış ve Yönetim Giderleri

İşletmenin müşterilerinin yaşam boyu değeri üç temel bileşenden oluştuğu şekil 2'de gösterilmektedir. Bunlar; net katkı payı, pazarlama giderleri ve ilgili dönemlerdeki satıs kârlılı̆ıdır. İşletme yöneticileri her bir müşterisi için MYBD tahmin ederek, müşterilerin kâra katkısını temel alan bir müşteri sıralaması ile işletmeye yönelik karar alma araçlarının yaratımasına yardımcı olmaktadır. 
Şekil 2. Müşteri Yaşam Boyu Değerini Hesaplama Süreci

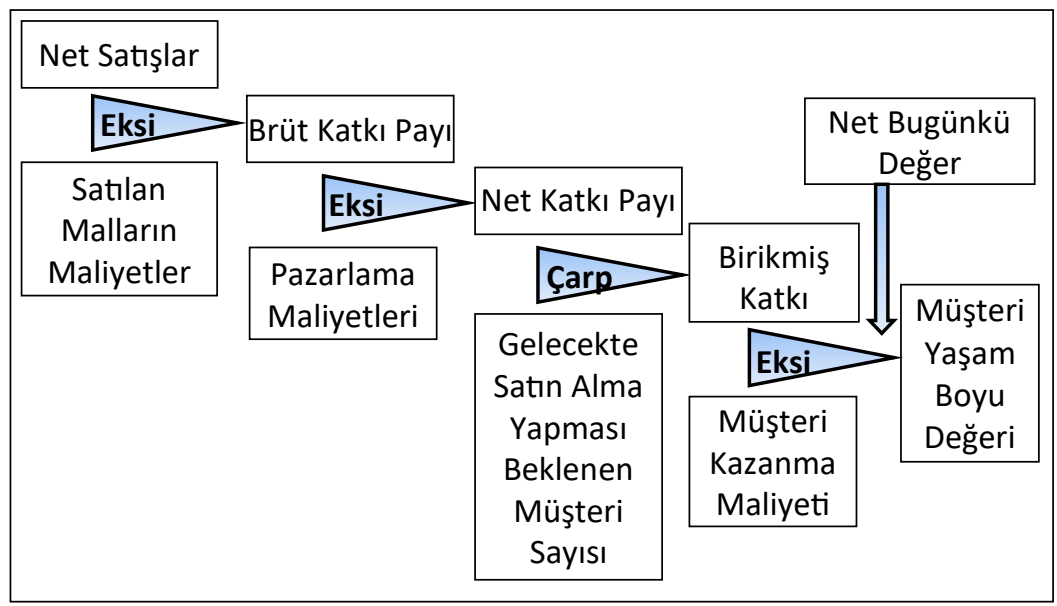

Kaynak: Model, V. Kumar ve B. Rajan, (2009), "Profitable Customer Management: Measuring and Maximizing Customer Lifetime Value", Management Accounting Quaterly, Spring, 10:3, s.2'den uyarlanmıştır.

Brüt satış kârı, satışlardan satılan malların maliyetinin düşülmesidir. Satılan malların maliyeti, hem sabit hem de değişken maliyetleri içermektedir. Ancak brüt katkı payı saţ̧̧ ve yönetim giderleri dâhil edilmemektedir.

Net katkı payı ise, brüt katkı payından değişken dönem giderlerinin düşülmesi sonucunda hesaplanmaktadır.

Müşteri yaşam boyu değerinin ölçülmesinde aşağıda belirtilen süreçlerin gözden geçirilmesinin gerekli olduğu ifade edilmektedir (Tarhan, 2016:30):

- Illk aşama analizin amacının ne olacağına karar verilmesidir. Bu kararlar oldukça açık olmasına karşın, birçok organizasyonda MYBD hesaplamalarından ne elde edilmesi beklendiği belli değildir. Genelde MYBD analizi spesifik özelliklere sahip müşterilerin yaşam boyu değerlerinin belirlenmesi için kullanılır.

- İkinci aşama analizin kullanılacağı dönemin belirlenmesidir. MYBD’nin hangi dönemler arasında ölçüleceği, müşteri kaçışlarını ve müşteri kazanımlarını açıkladığı için önemlidir.

- Üçüncü aşama hesaplamanın müşteri bölümleri bazlı yapılıp yapılmayacağının belirlenmesidir.

- Dördüncü aşama müşteri davranışlarının her bir satın alma düzeyinde geçmişe yönelik olarak analiz edilmesidir. Bu müşteri kayıp oranlarının bulunması ve satın alma geçmişinin öğrenilmesi için önemlidir.

- Son aşama bir stratejinin geliştirilmesidir.

\section{Müşteri Yaşam Boyu Değeri Modelleri}

Müşteri yaşam boyu değeri hesaplama modelleri daha önce de belirtildiği üzere sektörden sektöre, işletmeye, işletmenin içinde bulunduğu bölgeye, işletme müşterilerine göre farklılık gösterebilmektedir. Bununla birlikte modellerin büyük bir çoğunluğunun, hesaplamalarda müşterilerin sadece gelecekteki değerlerini göz önünde bulundurdukları, başka bir ifadeyle geleceğe yönelik oldukları gözlemlenmiştir (Yapraklı ve Keser, 2008:485). 
En genel anlamda, bu modelleri ikiye ayırmak mümkündür: geçmiş davranış esaslı modeller ve gelecek-geçmiş davranış esaslı modeller. Gelecek-geçmiş davranış esaslı modeller ise kendi içerisinde iki gruba ayrılabilmektedir: müşteri elde etme maliyetini içermeyen modeller ve müşteri elde etme maliyetini içeren modeller (Hızıroğlu ve Şengül, 2012:2; Tarhan, 2016:33).

Bu modellerin hepsi müşteri veri tabanında bulunan geçmiş verilerden yaralanarak müşteri yaşam boyu değeri hesaplamaktadırlar. Geçmiş davranış esaslı modeller ve gelecek-geçmiş davranış esasılı modellerin birbirinden ayrıldıkları temel nokta, müşterilerin gelecekte aktif olup olmadıkları açısından değerlendirilmesidir. Gelecek-geçmiş davranış esaslı modeller müşterinin gelecekteki aktivasyonunu temel alarak hesaplama yaparken, geçmiş davranış esaslı modeller bu değerlendirmeyi göz önünde bulundurmaz. Bu iki temel sınıfin birbirinden ayrıldıkları bir diğer önemli husus, müşteri maliyetlerini gelecek-geçmiş davranış esaslı modeller göz önünde bulundururken, geçmiş davranış esaslı modeller göz önünde bulundurmazlar. Gelecek-geçmiş davranış esaslı modellerin iki gruba ayrılmasının temelinde ise müşteriyi elde etme maliyetlerini hesaba katıp katmamaları Şekil 3'te gösterilmektedir. (Hızıroğlu ve Şengül, 2012:2).

Şekil 3. Müşteri Yaşam Boyu Değerlerinin Sınıflandırılması

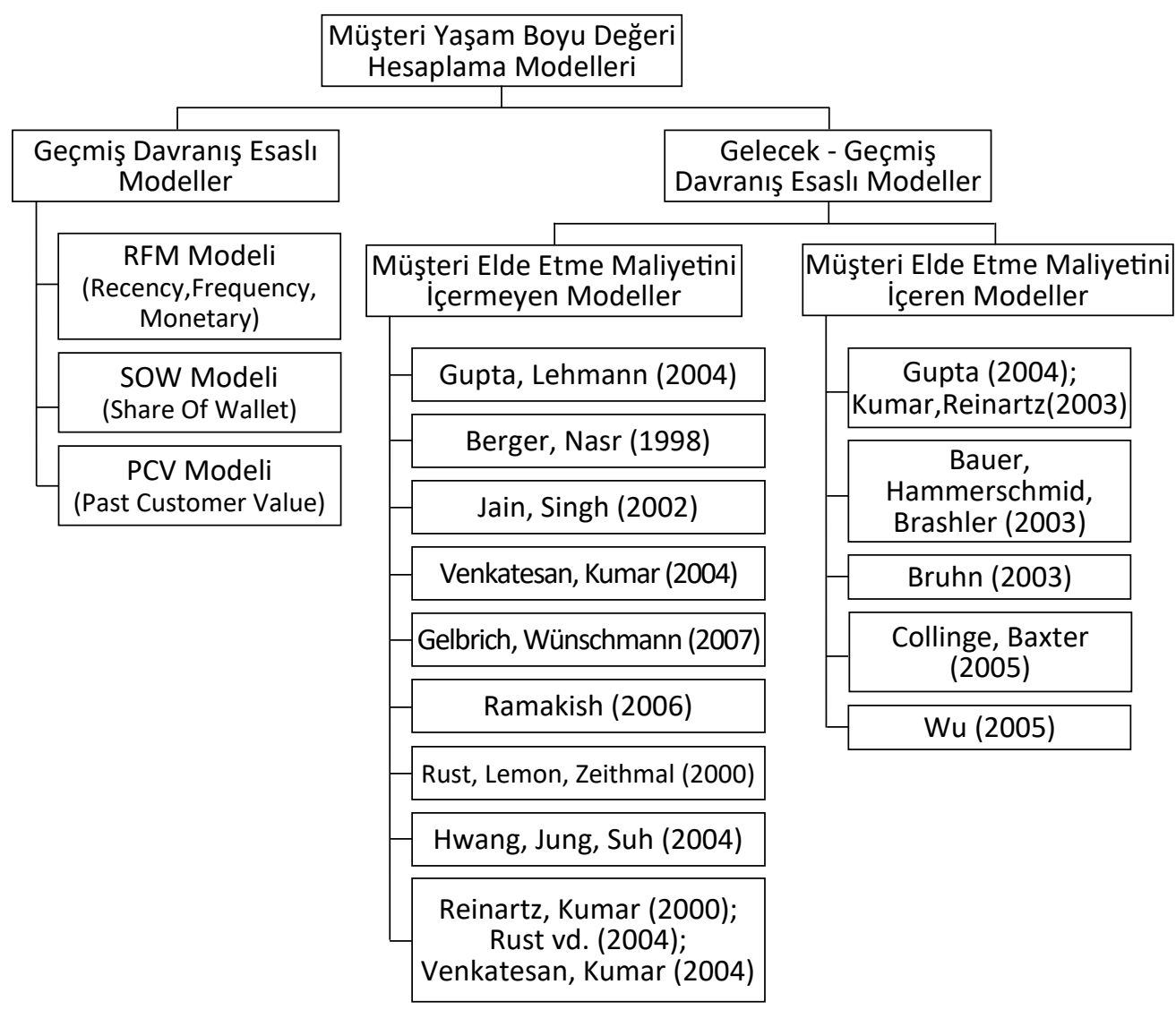

Kaynak: Hızıroğlu \& Şengül, 2012:2.

Müşteri yaşam boyu değerinin hesaplanmasına yönelik bu matematiksel modellerden bazıları aşağıda ayrıntılı bir şekilde açıklanmıştır.

\subsection{Müşteri Yaşam Boyu Değeri Hesaplama Modelleri}

Müşteri yaşam boyu değerinin hesaplanmasına ilişkin olarak birçok model geliştirmiştir. Ancak bu modellerden en fazla kabul gören modeller; Gupta-Lehmann modeli, Jain-Singh modeli, Bruhn modeli ve RFM modelidir. Bu modeller üzerinde detaylı açıklamalar yapılacaktır. 


\subsubsection{Gupta ve Lehmann'ın Müşteri Yaşam Boyu Değeri Hesaplama Modeli}

Gupta ve Lehman (2003) müşteri hayat boyu değerini, bir müşteriden elde edilmesi beklenen kârların tümünün net bugünkü değeri olarak görmektedirler. Bu modeldeki temel varsayım, genelde müşterinin firma ile ne kadarlık bir zaman aralığında beraber olacağı ve o zaman dönemi için ne kadarlık bir nakit akışı sağlayacağının bilinmesidir. (Gupta ve Lehmann, 2003:88,89).

Bu modele göre müşteri yaşam boyu değerinin kolaylıkla hesaplanabilmesi için su varsayımları kabul etmişlerdir (Gupta ve Lehmann, 2003:93):

1. Kâr payları zaman içinde değişmezler, sabittirler.

2. Elde tutma oranı zamana karşı sabittir.

3. Projeksiyon periyodu $\mathrm{n}$ sonsuzdur.

Gupta Lehmann modeli iş hayatında kullanım için çok uygundur. Elde tutma oranı, geçen yılki müşterilerden ne kadarı halen cari yılda da müşterimiz olduğu gösteren orandır. Bir yönetici şirketinin elde tutma oranı ve büyüme oranını biliyorsa, rahatıkla müşterisinin hayat boyu değeri hakkında fikir sahibi olabilir ve bu doğrultuda hızlı, yerinde kararlar verebilir (Tarhan, 2016:35-45).

\subsubsection{Jain ve Singh'in Müşteri Yaşam Boyu Değeri Hesaplama Modeli}

Bu modelde nakit akışlarının belirli bir zaman periyodunun sonunda gerçekleştiği düşünülmektedir. Bu model bir müşterinin gelecekteki nakit akışlarının net şimdiki değerine dayanan müşteri yaşam boyu değeri modellerinin farklı bir çeşidini belirtir. Nakit akışlarının gerçekleşme zamanının her bir dönem için aynı olduğu varsayılmaktadır. Aynı zamanda sadece firmayla ilişki içerisinde bulunan müşteriler dikkate alınmakta, olası ve geçmiş müşteriler göz ardı edilmektedir (Jain ve Singh, 2002:37).

\subsubsection{Bruhn'un Müşteri Yaşam Boyu Değeri Hesaplama Modeli}

Model kapsamında müşteri doğrudan yatırım olarak değerlendirilmektedir. Modelde gelecek dönemlerdeki cirolar ve oluşabilecek maliyetler ürün bazında (birim başına düşen) ele alınmaktadır. Ayrıca müşteri kazanım maliyetleri de modele bir kez dâhil edilmektedir. Modelde ciro ve maliyetlerin birim bazına indirgenmesi, modelin sadece belirli sektörlerde (örneğin; dayanıklı tüketim ürünleri, yatırım ürünleri vb.) kullanılmasına olanak vermektedir. Bu ise model için en önemli kısıtı oluşturmaktadır (Scheneider ve Sağlam, 2007: 33-35).

\subsection{RFM Modeli}

RFM analizi, pazarlamada özellikle direk pazarlamada en çok bilinen ve uygulanan müşteri bölümleme yöntemlerinden biridir. RFM; Recency, Frequency, Monetary kelimelerinin baş harflerinden oluşur. Recency, müşterinin son işleminin güncelliğine, frequency işlem sıklığına, monetary de müşterinin harcadığı toplam parayı ifade etmektedir. RFM analizi 1970'li yıllardan beridir kullanılan bir yöntemdir (Berry ve Linoff, 2004: 447-70). Mevcut müşterilerimiz arasında yeni bir teklife cevap vermeye en hazır olanı hangisidir sorusuna cevap veren bir tekniktir. Bu teknik genellikle doğrudan pazarlamada kullanılır.

RFM'i hesaplamada genellikle iki yöntem kullanılır. Illk yöntem, RFM ölçütlerine dayanarak müşteri veri tabanından verilerin toplanması, bu verilerin eşit ölçülerde gruplanması ve bunların analizidir.

ikinci yöntem ise, $\mathrm{R}, \mathrm{F}$ ve $\mathrm{M}$ için regresyon analizini kullanmak yoluyla nisbi ağırlıklı ortalamaların (relative weights) hesaplanmasını ve bunun ardından bu ağırlıklı ortalamaların RFM'in bütünleşik etkisini hesaplamak için kullanılmasını kapsar. RFM bu durumda bir müşteri için $R, F$ ve $M^{\prime}$ 'in ağırlıklandırılmış değerlerinin bir toplamı olarak dikkate alınır.

Bu modelin temel varsayımı en son alışveriş yapmış, en sık alışveriş yapan ve en fazla harcamayı yapmış müşterilerin en iyi müşteri olduğu ve bu müşterinin gelecek dönemde de aynı davranışları 
sergileyeceği ve muhtemelen en kârlı müşteri olacağı için firma için en değerli müşteri olacağıdır (Keiningham vd., 2006:37).

\section{Bulgular ve Değerlendirme}

İşletmeler, yoğun rekabet ortamında hayatını sürdürebilmek için ticari faaliyetlerini müşteri odaklı bir şekilde sürdürmek durumundadır. Bu nedenle de müşterilerini tüm detaylarıyla tanımlamalı, müşterileri bölümlere ayırmalı, sürekliliğini sağlamalıdır. Bu amaçla elektrik malzemesi sektöründe faaliyet gösteren (A) İsletmenin verilerinden yararlanarak, RFM modeli ve MYBD hesaplanacaktır. MYBD hesaplanmasında; Gupta ve Lehmann'ın, Jain ve Singh'in ve Bruhn'un MYBD hesaplama modelleri kullanılacaktır. Problem; araştrrmaya konu firma için değerli olan müşterileri belirlemek, bölümlemek ve işletmenin müşteri stratejisini oluşturabilmektir. Analiz çalışması için Excel 2013 programları kullanılmaktadır.

\subsection{Müşteri Yaşam Boyu Değeri Analizi}

Araştırmaya kaynak olabilecek veriler; (A) İşletmesinin muhasebe, bilgi işlem ve pazarlama bölümlerinden alınmıştır. Analizde kullanılacak olan; müşteri numarası, işlem tarihleri, miktarı, satış tutarı, satılan malın maliyeti, değişken pazarlama gideri verileri işletmeden temin edilmiştir. 56 adet tüzel kişi niteliği olan müşterinin 2013, 2014 ve 2015 dönemlerinin 11.302 satışa bağlı kayıtları incelenmiştir. Müşterilerin brüt satış değerlerinden; satış iadesi, satış iskontosu, satışa bağlı promosyon, satış gideri gibi tüm satış indirimleri çıkartılarak müşteri bazında net satış tutarına ulaşılmıştır ve bu veriler Tablo 1'de gösterilmiştir. Ayrıca her bir müşterinin her bir net satış değerine ait saţ̧ maliyeti çıkartlarak her bir satışa ilişkin brüt satış kârına ulaşılmıştr. Değişken pazarlama giderleri de her bir satış ile ilişkilendirerek, müşteri başına düşen toplam değişken pazarlama giderleri belirlenmiştir. Böylece işletmenin her bir müşterine ilişkin net katkı payına hesaplanabilmiştir.

Tablo 1. Analize Yönelik Hazırlanmış İşletme Verileri

\begin{tabular}{|c|c|c|c|c|c|c|}
\hline $\begin{array}{c}2013 \\
\text { ID } \\
\end{array}$ & $\begin{array}{c}\text { Illk Sipariş } \\
\text { Tarihi } \\
\end{array}$ & Son Sipariş Tarihi & $\begin{array}{c}\text { Net Satış } \\
\text { Tutarı }\end{array}$ & $\begin{array}{c}\text { Satış } \\
\text { Maliyeti }\end{array}$ & Brüt Satış Karı & $\begin{array}{c}\text { Değişken } \\
\text { Pazarlama } \\
\text { Maliyeti }\end{array}$ \\
\hline 1 & 3.01.2013 & 30.12 .2013 & 529.082 & 314.485 & 214.597 & 17.032 \\
\hline 2 & 3.01.2013 & 30.12 .2013 & 1.106 .453 & 607.259 & 499.193 & 35.034 \\
\hline 30 & 9.08 .2013 & 31.10 .2013 & 23.100 & 11.550 & 11.550 & 723 \\
\hline 31 & 3.01 .2013 & 30.12 .2013 & 687.806 & 393.106 & 294.700 & 21.163 \\
\hline 32 & 3.01 .2013 & 30.12.2013 & 1.438 .389 & 759.074 & 679.315 & 44.258 \\
\hline 33 & 3.01 .2013 & 30.12 .2013 & 1.793 .719 & 1.001 .963 & 791.756 & 55.191 \\
\hline 34 & 3.01.2013 & 30.12 .2013 & 200.716 & 111.683 & 89.033 & 6.176 \\
\hline 35 & 8.01 .2013 & 26.12.2013 & 503.458 & 279.105 & 224.353 & 15.491 \\
\hline 36 & 17.01 .2013 & 30.12 .2013 & 321.817 & 175.451 & 146.366 & 9.902 \\
\hline 37 & 10.01.2013 & 28.12.2013 & 50.073 & 27.181 & 22.892 & 1.541 \\
\hline 50 & 2.01.2013 & 30.12 .2013 & 1.197.281 & 723.062 & 474.219 & 36.839 \\
\hline 51 & 2.01 .2013 & 25.12 .2013 & 323.750 & 175.192 & 148.558 & 9.962 \\
\hline 52 & 10.01.2013 & 26.12.2013 & 176.032 & 93.211 & 82.821 & 5.416 \\
\hline 53 & 3.05 .2013 & 24.12.2013 & 1.454 .686 & 809.364 & 645.322 & 44.760 \\
\hline 54 & 14.01.2013 & 30.12 .2013 & 272.885 & 138.667 & 134.218 & 8.396 \\
\hline 55 & 3.01 .2013 & 30.12.2013 & 621.381 & 349.574 & 271.807 & 19.119 \\
\hline 56 & 20.08.2013 & 18.12.2013 & 67.633 & 34.852 & 32.781 & 2.081 \\
\hline
\end{tabular}


Müşterilere yönelik RFM ve MYBD analizleri yapabilmek için, işletmeden ayrıca müşterilerin her dönem ilişkin sevkiyat sayısı, yıl bazında müşterilerle çalışma süresi, müşteri elde etme oranları, müşteri bazında brüt satış kârı oranı verileri de alınmıştır. Bu durum Tablo 2'de örneklendirilmiştir.

Tablo 2. İşletmenin Müşterilerine iliş̧kin Veriler

\begin{tabular}{|r|c|c|c|r|r|r|}
\hline $\begin{array}{c}2013 \\
\text { ID }\end{array}$ & $\begin{array}{c}\text { Sevkiyat } \\
\text { Sayısı }\end{array}$ & $\begin{array}{c}\text { Müşteri } \\
\text { Ömrü (YıI) }\end{array}$ & $\begin{array}{c}\text { Müşteri Elde } \\
\text { Tutma Oranı }\end{array}$ & Brüt Satış Karı & $\begin{array}{c}\text { Müşteri } \\
\text { Kazanma } \\
\text { Maliyeti (I0) }\end{array}$ & \multicolumn{1}{c|}{$\begin{array}{c}\text { Değişken } \\
\text { Pazarlama } \\
\text { Maliyeti }\end{array}$} \\
\hline 1 & 116 & 20 & $95 \%$ & 214.597 & 23.466 & 17.032 \\
\hline 2 & 184 & 20 & $100 \%$ & 499.193 & 37.223 & 35.034 \\
\hline 3 & 206 & 20 & $100 \%$ & 578.213 & 41.673 & 43.453 \\
\hline 4 & 33 & 20 & $98 \%$ & 65.050 & 6.676 & 4.962 \\
\hline 5 & 72 & 18 & $100 \%$ & 163.991 & 14.565 & 12.338 \\
\hline 6 & 53 & 20 & $100 \%$ & 107.191 & 10.722 & 7.957 \\
\hline 7 & 8 & 20 & $100 \%$ & 16.772 & 1.618 & 1.236 \\
\hline 8 & 178 & 16 & $100 \%$ & 333.221 & 36.009 & 30.285 \\
\hline 9 & 60 & 20 & $100 \%$ & 156.797 & 12.138 & 11.659 \\
\hline 10 & 168 & 20 & $100 \%$ & 715.815 & 33.986 & 48.210 \\
\hline 11 & 2 & 5 & $90 \%$ & 6.850 & 405 & 431 \\
\hline
\end{tabular}

Müşterilerin belirlenen dönemde gerçekleşen toplam satı̧ cirosunun ilgili dönemdeki toplam satı̧̧ (sevkiyat) sayısına bölünmesiyle ortalama sevkiyat tutarı veya sepet ortalaması hesaplanmaktadır. Bu değer bir müşterinin her bir satş işlemi ile işletmede yarattğı ortalama satış cirosu tespit edilebilmektedir. Ayrıca Tablo 3'te müşterinin işletmeye çalıştğı süre ile yıllık net satış tutarı ile çarpılarak müşteri ömrü toplam satış cirosu hesaplanmaktadır. Müşterinin ömrü boyunca tahmini toplam satı̧ tutarı üzerinden işletmenin müşterisinden ömrü boyunca elde ettiği tahmini toplam kârı da belirlenmektedir.

Tablo 3. RFM ve MYBD’ne Yönelik Temel Veriler

\begin{tabular}{|r|c|r|c|r|r|r|r|}
\hline $\begin{array}{c}2013 \\
\text { ID }\end{array}$ & $\begin{array}{c}\text { Sevkiyat } \\
\text { Sayısı }\end{array}$ & $\begin{array}{c}\text { Net Satış } \\
\text { Tutarı }\end{array}$ & $\begin{array}{c}\text { Müşteri } \\
\text { Ömrü (Yıl) }\end{array}$ & $\begin{array}{c}\text { Brüt Satış } \\
\text { Karlılık \% }\end{array}$ & $\begin{array}{c}\text { Ortalama } \\
\text { Sevkiyat } \\
\text { Tutarı }\end{array}$ & $\begin{array}{c}\text { Müşteri Ömrü } \\
\text { Toplam Satış } \\
\text { Cirosu }\end{array}$ & $\begin{array}{c}\text { Müşteri } \\
\text { Ömrü } \\
\text { Toplam Karı }\end{array}$ \\
\hline 17 & 112 & 459.646 & 20 & 0,43 & 4.104 & 9.192 .910 & 3.947 .073 \\
\hline 18 & 159 & 1.049 .405 & 20 & 0,44 & 6.600 & 20.988 .092 & 9.173 .687 \\
\hline 19 & 21 & 97.218 & 12 & 0,45 & 4.629 & 1.166 .615 & 522.440 \\
\hline 20 & 188 & 920.985 & 20 & 0,37 & 4.899 & 18.419 .706 & 6.850 .719 \\
\hline 21 & 50 & 249.038 & 20 & 0,44 & 4.981 & 4.980 .760 & 2.177 .695 \\
\hline 22 & 15 & 135.409 & 20 & 0,45 & 9.027 & 2.708 .173 & 1.216 .800 \\
\hline 23 & 109 & 1.118 .989 & 20 & 0,42 & 10.266 & 22.379 .778 & 9.429 .954 \\
\hline 24 & 32 & 209.911 & 14 & 0,47 & 6.560 & 2.938 .756 & 1.385 .685 \\
\hline
\end{tabular}

(A) İşletmesinin MYBD hesaplamasında gerekli indirgeme oranı 0,1 olarak kabul edilmiştir.

\subsubsection{Gupta ve Lehmann'na Göre MYBD Hesaplaması}

(A) Işletmesinin yıllar itibariyle gerçekleştirdiği her bir saţ̧̧a ilişkin; "Müşteri ID", "Net Satı̧ Tutarı", "Saţşların Maliyeti" ve "Müşteri Elde Tutma Oranı" verileri Gupta ve Lehmann'ın formülünde kullanılmaktadır. 
Tablo 4. Gupta Ve Lehmann'a Göre MYBD Hesaplanması

\begin{tabular}{|r|r|c|r|r|r|r|r|}
\hline $\begin{array}{r}\text { 2013 } \\
\text { ID }\end{array}$ & $\begin{array}{c}\text { Net Satış } \\
\text { Tutarı }\end{array}$ & $\begin{array}{c}\text { Müşteri Elde } \\
\text { Tutma Oranı }\end{array}$ & $\begin{array}{c}\text { Satış } \\
\text { Maliyeti }\end{array}$ & $\begin{array}{c}\text { Brüt Satış } \\
\text { Karı }\end{array}$ & $\begin{array}{c}\text { Brüt Satış } \\
\text { Karlılık \% }\end{array}$ & $\begin{array}{c}\text { Ortalama } \\
\text { Sevkiyat } \\
\text { Tutarı }\end{array}$ & m.(r/1+i-r) \\
\hline 20 & 920.985 & $100 \%$ & 578.449 & 342.536 & 0,37 & 4.899 & 3.425 .359 \\
\hline 21 & 249.038 & $100 \%$ & 140.153 & 108.885 & 0,44 & 4.981 & 1.088 .848 \\
\hline 22 & 135.409 & $100 \%$ & 74.569 & 60.840 & 0,45 & 9.027 & 608.400 \\
\hline 23 & 1.118 .989 & $100 \%$ & 647.491 & 471.498 & 0,42 & 10.266 & 4.714 .977 \\
\hline 24 & 209.911 & $100 \%$ & 110.934 & 98.978 & 0,47 & 6.560 & 989.775 \\
\hline 25 & 6.700 & $98 \%$ & 3.685 & 3.015 & 0,45 & 6.700 & 24.623 \\
\hline 26 & 477.985 & $100 \%$ & 279.660 & 198.326 & 0,41 & 6.828 & 1.983 .256 \\
\hline 27 & 52.025 & $100 \%$ & 27.881 & 24.143 & 0,46 & 4.335 & 241.434 \\
\hline 28 & 16.200 & $80 \%$ & 8.100 & 8.100 & 0,50 & 8.100 & 21.600 \\
\hline 29 & 13.600 & $95 \%$ & 8.160 & 5.440 & 0,40 & 6.800 & 34.453 \\
\hline 30 & 23.100 & $75 \%$ & 11.550 & 11.550 & 0,50 & 7.700 & 24.750 \\
\hline 31 & 687.806 & $100 \%$ & 393.106 & 294.700 & 0,43 & 4.555 & 2.947 .000 \\
\hline
\end{tabular}

Hesaplamalar sonucunda 56 müşterinin Gupta ve Lehmann'ın müşteri yaşam boyu değeri skoru yıllara göre Tablo 4'te toplanmaktadır.

Her bir müşteri için 2013, 2014 ve 2015 dönemlerine ilişkin olarak hesaplanan MYBD, tek bir ortalama değere dönüştürülmektedir. Gupta ve Lehmann'a göre hesaplanan aritmetik ortalama Tablo 5 'te gösterilmektedir.

Tablo 5. Yıllar İtibariyle Gupta Ve Lehmann'a Göre MYBD

\begin{tabular}{|r|r|r|r|r|}
\hline & \multicolumn{4}{|c|}{ Gupta ve Lehmann'In MYBD } \\
\hline \multicolumn{1}{|c|}{ ID } & \multicolumn{1}{|c|}{$\mathbf{2 0 1 3}$} & \multicolumn{1}{c|}{$\mathbf{1 0 1 4}$} & \multicolumn{1}{c|}{$\mathbf{2 0 1 5}$} & \multicolumn{1}{c|}{ ORT. } \\
\hline 1 & 1.359 .112 & 1.932 .324 & 2.745 .910 & 2.012 .449 \\
\hline 2 & 4.991 .934 & 2.761 .918 & 8.238 .761 & 5.330 .871 \\
\hline 3 & 5.782 .128 & 5.200 .478 & 8.487 .183 & 6.489 .930 \\
\hline 4 & 531.243 & 80.028 & 394.535 & 335.269 \\
\hline 5 & 1.639 .911 & 2.540 .364 & 3.190 .338 & 2.456 .871 \\
\hline 6 & 1.071 .906 & 946.177 & 3.357 .690 & 1.791 .924 \\
\hline 7 & 167.724 & 133.055 & 314.934 & 205.238 \\
\hline 8 & 3.332 .209 & 3.004 .944 & 4.924 .413 & 3.753 .855 \\
\hline 9 & 1.567 .966 & 1.165 .813 & 1.905 .841 & 1.546 .540 \\
\hline 10 & 7.158 .155 & 8.766 .792 & 19.103 .429 & 11.676 .125 \\
\hline 11 & 30.825 & 3.849 .849 & 14.100 .142 & 8.990 .408 \\
\hline 12 & 660.287 & 1.163 .047 & 1.620 .606 & 1.147 .980 \\
\hline
\end{tabular}

\subsubsection{Jain ve Singh'ne Göre MYBD Hesaplaması}

(A) İ̧̧letmesinde gerçekleştirilen her bir satişa ilişkin olarak, "Müşteri ID", "Ortalama Müşteri Ömrü", "Satış Tutarı" - "Satılan Ticari Malların Maliyeti" veya "Brüt Satış Kârı" verilerinden yararlanarak MYBD hesaplanabilmektedir. Nakit akışlarının belirli bir zamanın sonunda gerçekleştiği düşünülmekte ve bu nedenle de indirgeme oranında yararlanılmaktadır. Çalışmada (A) İşletmesinin indirgeme oranı 0,1 olarak kabul edilmiştir. 
Tablo 6. Jain ve Singh'ne Göre MYBD Hesaplanması

\begin{tabular}{|r|r|r|r|r|r|}
\hline $\begin{array}{r}\text { 2013 } \\
\text { ID }\end{array}$ & $\begin{array}{c}\text { Net } \\
\text { Satış Tutarı }\end{array}$ & $\begin{array}{c}\text { Müşteri } \\
\text { Ömrü (Yıl) }\end{array}$ & $\begin{array}{c}\text { Brüt } \\
\text { Satış Karı }\end{array}$ & $\begin{array}{c}\mathbf{d} \\
\text { indirgeme } \\
\text { oranı }\end{array}$ & $\sum_{i=1}^{n} \frac{\left(R_{i}-C_{i}\right.}{(1+d)^{i-0,5}}$ \\
\hline 1 & 529.082 & 20 & 214.597 & 0,1 & 3.920 .397 \\
\hline 2 & 1.106 .453 & 20 & 499.193 & 0,1 & 9.119 .600 \\
\hline 3 & 1.379 .783 & 20 & 578.213 & 0,1 & 10.563 .178 \\
\hline 4 & 154.396 & 20 & 65.050 & 0,1 & 1.188 .380 \\
\hline 5 & 387.275 & 18 & 163.991 & 0,1 & 2.696 .309 \\
\hline 6 & 247.551 & 20 & 107.191 & 0,1 & 1.958 .229 \\
\hline 7 & 38.517 & 20 & 16.772 & 0,1 & 306.409 \\
\hline 8 & 950.172 & 16 & 333.221 & 0,1 & 4.870 .002 \\
\hline 9 & 368.628 & 20 & 156.797 & 0,1 & 2.864 .465 \\
\hline 10 & 1.550 .997 & 20 & 715.815 & 0,1 & 13.076 .997 \\
\hline 11 & 13.700 & 5 & 6.850 & 0,1 & 31.285 \\
\hline
\end{tabular}

Bu modele göre yapılan hesaplamalar sonucunda 56 müşterinin MYBD yıllar itibariyle Tablo 6'da gösterilmektedir.

Tablo 7. Yıllar İtibariyle Jain ve Singh'e Göre MYBD

\begin{tabular}{|r|r|r|r|r|}
\hline \multicolumn{5}{|c|}{ Jain ve Singh'in MYBD } \\
\hline \multicolumn{1}{|r|}{ ID } & \multicolumn{1}{|c|}{$\mathbf{2 0 1 3}$} & \multicolumn{1}{c|}{$\mathbf{2 0 1 4}$} & \multicolumn{1}{c|}{$\mathbf{2 0 1 5}$} & \multicolumn{1}{c|}{ ORT. } \\
\hline 1 & 3.920 .397 & 5.405 .465 & 4.437 .219 & 4.587 .694 \\
\hline 2 & 9.119 .600 & 7.726 .162 & 12.522 .694 & 9.789 .485 \\
\hline 3 & 10.563 .178 & 14.547 .767 & 12.988 .030 & 12.699 .659 \\
\hline 4 & 1.188 .380 & 223.870 & 595.696 & 669.315 \\
\hline 5 & 2.696 .309 & 6.429 .591 & 4.471 .177 & 4.532 .359 \\
\hline 6 & 1.958 .229 & 2.646 .825 & 4.242 .813 & 2.949 .289 \\
\hline 7 & 306.409 & 372.208 & 480.692 & 386.437 \\
\hline 8 & 4.870 .002 & 6.804 .858 & 8.233 .077 & 6.635 .979 \\
\hline 9 & 2.864 .465 & 3.261 .233 & 2.896 .500 & 3.007 .399 \\
\hline 10 & 13.076 .997 & 24.524 .137 & 28.965 .978 & 22.189 .038 \\
\hline 11 & 31.285 & 3.077 .009 & 7.079 .156 & 5.093 .725 \\
\hline 12 & 844.379 & 2.323 .926 & 1.844 .870 & 1.671 .058 \\
\hline
\end{tabular}

Her bir müşteri için 2013, 2014 ve 2015 dönemlerine ilişkin olarak hesaplanan MYBD, tek bir ortalama değere dönüştürülmektedir. Jain ve Singh'a göre hesaplanan aritmetik ortalama Tablo 7'de gösterilmektedir.

\subsubsection{Bruhn'a Göre MYBD Hesaplaması}

(A) İşletmesinin yıllar itibariyle gerçekleştirdiği satş̧lara ilişkin; "Müşteri ID", "Ortalama Müşteri Ömrü", "Satı̧ Tutarı", "Satı̧ Ticari Maliyeti", "Müşteri Kazanma Maliyeti" ve "Değişken Pazarlama Giderleri" üzerinden hesaplama gerçekleştirilmektedir. Bruhn'un yıllar itibariyle 56 müşterinin yaşam boyu değerlerinin hesaplanması Tablo 8' de gösterilmektedir. 
Tablo 8. Bruhn'a Göre MYBD Hesaplanması

\begin{tabular}{|c|c|c|c|c|c|c|c|}
\hline $\begin{array}{c}2013 \\
\text { ID }\end{array}$ & $\begin{array}{l}\text { Müşteri_- } \\
\text { Ömrü (YıI) }\end{array}$ & $\begin{array}{c}\text { Müşteri } \\
\text { Elde } \\
\text { Tutma } \\
\text { Oran }\end{array}$ & $\begin{array}{c}\text { Brüt Satış } \\
\text { Karı }\end{array}$ & $\begin{array}{c}\text { Müşteri } \\
\text { Kazanma } \\
\text { Maliyeti } \\
\left(I_{0}\right)\end{array}$ & $\begin{array}{c}\text { Değişken } \\
\text { Pazarlama } \\
\text { Maliyeti }\end{array}$ & $\begin{array}{c}\mathbf{r} \\
\text { indirgeme } \\
\text { oranı }\end{array}$ & $\begin{array}{l}\mathrm{I}_{0} \\
+\sum_{t=0}^{T} \mathbf{x}_{\mathrm{t}}(\mathbf{p}-\mathbf{k}) \\
-\mathbf{M}_{\mathrm{t}} \frac{\mathrm{R}_{\mathrm{t}}}{(1+\mathrm{r})^{\mathrm{t}}}\end{array}$ \\
\hline 1 & 20 & $95 \%$ & 214.597 & 23.466 & 17.032 & 0,1 & 4.267 .297 \\
\hline 2 & 20 & $100 \%$ & 499.193 & 37.223 & 35.034 & 0,1 & 9.916 .940 \\
\hline 3 & 20 & $100 \%$ & 578.213 & 41.673 & 43.453 & 0,1 & 11.476 .747 \\
\hline 4 & 20 & $98 \%$ & 65.050 & 6.676 & 4.962 & 0,1 & 1.293 .223 \\
\hline 5 & 18 & $100 \%$ & 163.991 & 14.565 & 12.338 & 0,1 & 2.933.393 \\
\hline 6 & 20 & $100 \%$ & 107.191 & 10.722 & 7.957 & 0,1 & 2.130 .879 \\
\hline 7 & 20 & $100 \%$ & 16.772 & 1.618 & 1.236 & 0,1 & 333.393 \\
\hline 8 & 16 & $100 \%$ & 333.221 & 36.009 & 30.285 & 0,1 & 5.295 .516 \\
\hline 9 & 20 & $100 \%$ & 156.797 & 12.138 & 11.659 & 0,1 & 3.113 .409 \\
\hline
\end{tabular}

Her bir müşteri için 2013, 2014 ve 2015 dönemlerine ilişkin olarak hesaplanan MYBD, tek bir ortalama değere dönüştürülmektedir. Bruhn'a göre hesaplanan aritmetik ortalama Tablo 9'da verilmektedir.

Tablo 9. Bruhn'un MYBD Hesaplanma Modeline Göre Elde Edilen Değerler

\begin{tabular}{|r|r|r|r|r|}
\hline \multicolumn{5}{|c|}{ Bruhn'un MYBD } \\
\hline \multicolumn{1}{|c|}{ ID } & \multicolumn{1}{c|}{$\mathbf{2 0 1 3}$} & \multicolumn{1}{c|}{$\mathbf{2 0 1 4}$} & \multicolumn{1}{c|}{$\mathbf{2 0 1 5}$} & \multicolumn{1}{c|}{ Ortalama } \\
\hline 1 & 4.267 .297 & 5.888 .283 & 4.826 .740 & 4.994 .107 \\
\hline 2 & 9.916 .940 & 8.408 .755 & 13.619 .545 & 10.648 .414 \\
\hline 3 & 11.476 .747 & 15.828 .000 & 14.129 .726 & 13.811 .491 \\
\hline 4 & 1.293 .223 & 243.707 & 648.330 & 728.420 \\
\hline 5 & 2.933 .393 & 6.997 .818 & 4.867 .604 & 4.932 .938 \\
\hline 6 & 2.130 .879 & 2.882 .730 & 4.626 .095 & 3.213 .235 \\
\hline 7 & 333.393 & 405.275 & 523.473 & 420.714 \\
\hline 8 & 5.295 .516 & 7.399 .575 & 8.946 .526 & 7.213 .872 \\
\hline 9 & 3.113 .409 & 3.547 .509 & 3.150 .618 & 3.270 .512 \\
\hline 10 & 14.206 .974 & 26.665 .043 & 31.475 .200 & 24.115 .739 \\
\hline 11 & 34.366 & 3.364 .234 & 7.729 .528 & 5.564 .064 \\
\hline
\end{tabular}

Tablo 10. MYBD Puanlarının Hesaplanması

\begin{tabular}{|c|r|r|r|r|c|}
\hline ID & $\begin{array}{c}\text { Gupta ve Lehmann'ın } \\
\text { Ortalama MYBD }\end{array}$ & $\begin{array}{c}\text { Jain ve Singh'in } \\
\text { Ortalama MYBD }\end{array}$ & $\begin{array}{c}\text { Bruhn'un Ortalama } \\
\text { MYBD }\end{array}$ & $\begin{array}{c}\text { Genel Ortalama } \\
\text { MYBD }\end{array}$ & $\begin{array}{c}\text { MYBD } \\
\text { Puanı }\end{array}$ \\
\hline 1 & 2.012 .449 & 4.587 .694 & 4.994 .107 & 3.864 .750 & 2 \\
\hline 2 & 5.330 .871 & 9.789 .485 & 10.648 .414 & 8.589 .590 & 4 \\
\hline 3 & 6.489 .930 & 12.699 .659 & 13.811 .491 & 11.000 .360 & 4 \\
\hline 4 & 335.269 & 669.315 & 728.420 & 577.668 & 1 \\
\hline 5 & 2.456 .871 & 4.532 .359 & 4.932 .938 & 3.974 .056 & 2 \\
\hline 6 & 1.791 .924 & 2.949 .289 & 3.213 .235 & 2.651 .483 & 2 \\
\hline 7 & 205.238 & 386.437 & 420.714 & 337.463 & 1 \\
\hline 8 & 3.753 .855 & 6.635 .979 & 7.213 .872 & 5.867 .902 & 3 \\
\hline 9 & 1.546 .540 & 3.007 .399 & 3.270 .512 & 2.608 .150 & 2 \\
\hline 10 & 11.676 .125 & 22.189 .038 & 24.115 .739 & 19.326 .967 & 5 \\
\hline 11 & 8.990 .408 & 5.093 .725 & 5.564 .064 & 6.549 .399 & 3 \\
\hline 12 & 1.147 .980 & 1.671 .058 & 1.821 .260 & 1.546 .766 & 1 \\
\hline 13 & 1.561 .457 & 3.527 .764 & 3.840 .407 & 2.976 .543 & 2 \\
\hline
\end{tabular}


İşletmenin genel MYBD ortalaması üzerinden Excel'in Veri Çözümleme aracılığıyla çizilen histograma dayalı olarak MYBD, 1 ile 7 arasında dağıtılmıştır. MYBD göstergeleri için en büyük 7 en küçük 1 olmak üzere toplam 7 adet puan atanmıştır. Bu durum Tablo 10'da verilmektedir.

Tablo 11'de MYBD aralığı ve puanlara bağlı olarak yüzdesel dağılım ortaya konulmaktadır. Buna göre müşterilerden MYBD olarak 1, 2, 3 ve 4 puanlarını alan 39 müşteridir ve bu müşterilerin toplam içindeki payı $\% 69,6$ 'dır. Bu MYBD puanlarına sahip müşterilerin toplam ortalama MYBD değerleri içindeki payı \%26,5'tir. MYBD olarak 5, 6 ve 7 puanlarını alan 17 müşteridir ve bu müşterilerin toplam içindeki payı \%30,4'tür. Bu MYBD puanlarına sahip müşterilerin toplam ortalama MYBD değerleri içindeki payı \%73,5'tir. MYBD puanlamasına göre müşteri ve maliyet dağılımı Tablo 11 'de gösterilmektedir.

MYBD, müşterilere yönelik yapılacak pazarlama ve muhasebe stratejilerinin belirlenmesinde önemli bir ölçüdür. Promosyonlar, satış politikaları, tutundurma faaliyetleri, vadeli satış politikaları gibi birçok farklılaşma ile müşterin kendilerini değerli hissetmeleri sağlanarak, müşteri sadakatinin artırılması da sağlanabilir. İşletmenin amacı az sayıda da olsa 5, 6 ve 7 MYBD puanı almış müşterilerin memnuniyetini artırmak ve sadık müşteri haline getirmek olmalıdır.

Tablo 11. MYBD'nin Puanlamaya Göre Dağılımı

\begin{tabular}{|l|r|r|r|r|r|r|}
\hline MYBD Aralığı & Puan & \multicolumn{1}{|c|}{ Dağılım (\%) } & MYBD Dağılımı & Ortalama MYBD & MYBD \% \\
\hline $0-2.400 .000$ & $\mathbf{1}$ & 13 & $\% 23,2$ & 17.118 .846 & 1.316 .834 & $\% 2,6$ \\
\hline $2.400 .001-4.200 .000$ & $\mathbf{2}$ & 11 & $\% 19,6$ & 36.549 .718 & 3.322 .702 & $\% 5,6$ \\
\hline $4.200 .001-8.500 .000$ & $\mathbf{3}$ & 8 & $\% 14,3$ & 50.447 .148 & 6.305 .893 & $\% 7,7$ \\
\hline $9.500 .001-15.000 .000$ & $\mathbf{4}$ & 7 & $\% 17,9$ & 106.566 .889 & 10.656 .689 & $\% 12,3$ \\
\hline $15.000 .001-25.500 .000$ & $\mathbf{5}$ & 6 & $\% 10,7$ & 109.001 .025 & 18.166 .837 & $\% 16,7$ \\
\hline $25.500 .001-36.000 .000$ & $\mathbf{6}$ & 4 & $\% 7,1$ & 127.171 .352 & 31.792 .838 & $\% 19,5$ \\
\hline 36.000 .001 ve üzeri & $\mathbf{7}$ & 4 & $\% 7,1$ & 205.620 .124 & 51.405 .031 & $\% 31,5$ \\
\hline Toplam & & $\mathbf{5 6}$ & $\mathbf{\% 1 0 0}$ & $\mathbf{6 5 2 . 4 7 5 . 1 0 1}$ & $\mathbf{1 2 4 . 4 3 7 . 6 7 6}$ & $\mathbf{\% 1 0 0}$ \\
\hline
\end{tabular}

\subsection{RFM Analizi}

RFM, müşterinin, en son ne zaman, hangi sıklıkta ve ne kadar parasını bizimle harcadığı sorularının yanıtıdır ve bileşenleri davranışsaldır. Bu faktörler müşteri davranışlarını tahmin etmek için kullanılır. Davranışı, şimdiki davranışa dayalı olarak tahmin etmek çok daha güçlü ve geçerli bir yöntemdir. RFM analizinin yapılabilmesi için tüm müşteri kayıtları, alımlarla ilgili belli tarihsel veriler bilinmeli ve uygun bir biçimde kodlanmış olmalıdır (Tarhan, 2016; [http://bekerman.com/blog/wpcontent/uploads/2014/09/DIYRFM.pdf (8.6.2016)]).

Tablo 12. RFM Analizinde Kullanılan Veriler

\begin{tabular}{|r|r|r|r|r|r|}
\hline $\begin{array}{c}2013 \\
\text { ID }\end{array}$ & $\begin{array}{c}\text { ilk Sipariş } \\
\text { Tarihi }\end{array}$ & $\begin{array}{c}\text { Son Sipariş } \\
\text { Tarihi }\end{array}$ & $\begin{array}{c}\text { Sevkiyat } \\
\text { Sayısı }\end{array}$ & $\begin{array}{c}\text { Net Satış } \\
\text { Tutarı }\end{array}$ & $\begin{array}{c}\text { Brüt Satış Karı } \\
\text { (BSK) }\end{array}$ \\
\hline 1 & 3.01 .2013 & 30.12 .2013 & 116 & 529.082 & 214.597 \\
\hline 2 & 3.01 .2013 & 30.12 .2013 & 184 & 1.106 .453 & 499.193 \\
\hline 3 & 3.01 .2013 & 30.12 .2013 & 206 & 1.379 .783 & 578.213 \\
\hline 4 & 3.01 .2013 & 30.12 .2013 & 33 & 154.396 & 65.050 \\
\hline 5 & 8.01 .2013 & 26.12 .2013 & 72 & 387.275 & 163.991 \\
\hline 6 & 17.01 .2013 & 30.12 .2013 & 53 & 247.551 & 107.191 \\
\hline 7 & 10.01 .2013 & 28.12 .2013 & 8 & 38.517 & 16.772 \\
\hline 8 & 3.01 .2013 & 30.12 .2013 & 178 & 950.172 & 333.221 \\
\hline 9 & 4.01 .2013 & 30.12 .2013 & 60 & 368.628 & 156.797 \\
\hline 10 & 20.04 .2013 & 31.12 .2013 & 168 & 1.550 .997 & 715.815 \\
\hline 11 & 8.08 .2013 & 12.12 .2013 & 2 & 13.700 & 6.850 \\
\hline
\end{tabular}


İşletmenin faaliyetleri sonucunda müşterilerine ilişkin "Müşteri ID", "Son Sipariş Tarihi", "Sevkiyat Sayısı", "Satı̧ Tutarı" ve "Brüt Saţ̧̧ Kârı" verileri analiz çalışması için girdi olarak alınmıştır. Bu veriler Tablo 12 'de verilmektedir.

RFM göstergeleri için en büyük 5 en küçük 1 olmak üzere 5 adet puan atanmıştır. Sektör yapısı gereği değerler farklı şekillerde tespit edilmiştir. R değeri için dönem sonuna yakınlık, F değeri için sevkiyat sıklığı ve $M$ değeri içinde hem satış tutarları hem de brüt satış kârı verileri esas alınmıştır. Bu aralıklar Tablo 13'te gösterilmektedir.

Tablo 13'teki RFM puanlama esaslarına göre 2013, 2014 ve 2015 dönemlerinde faaliyette bulunulan 56 müşterinin RFM değerleri Tablo 14'te oluşturmuştur.

Tablo 13. RFM Değeri Kriterleri

\begin{tabular}{|rrrr|}
\hline \multicolumn{4}{|c|}{$\mathbf{R}$} \\
\hline Sipariş verme süresi & \multicolumn{2}{|c|}{ Süre } & $\mathbf{R}$ \\
31.12 .13 & 22.12 .13 & 9 & $\mathbf{2 0}$ \\
21.12 .13 & 1.12 .13 & 20 & $\mathbf{1 5}$ \\
30.11 .13 & 10.11 .13 & 20 & $\mathbf{1 0}$ \\
9.11 .13 & 1.09 .13 & 69 & $\mathbf{5}$ \\
31.08 .13 & 15.05 .13 & 108 & $\mathbf{2}$ \\
14.05 .13 & 1.01 .13 & 133 & $\mathbf{1}$ \\
Yıl içinde hiç vermemişse & $\mathbf{0}$ & $\mathbf{0}$ \\
\hline
\end{tabular}

\begin{tabular}{|c|c|c|c|}
\hline \multicolumn{4}{|c|}{ M } \\
\hline \multicolumn{3}{|c|}{ Parasal değerler } & $\mathbf{M}$ \\
\hline \multirow{6}{*}{ 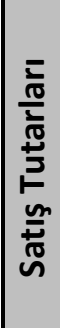 } & 2.020 .000 & 1.350 .000 & 25 \\
\hline & 1.349 .999 & 1.000 .000 & 20 \\
\hline & 999.999 & 500.000 & 15 \\
\hline & 499.999 & 200.000 & 10 \\
\hline & 199.999 & 100.000 & 5 \\
\hline & 99.999 & 1 & 1 \\
\hline \multicolumn{3}{|c|}{ Hiç satış yapılmamış } & 0 \\
\hline \multirow{5}{*}{ 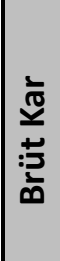 } & 1.000 .000 & 550.000 & 25 \\
\hline & 549.999 & 200.000 & 15 \\
\hline & 199.999 & 105.000 & 5 \\
\hline & 104.999 & 50.000 & 2 \\
\hline & 49.999 & 1 & 1 \\
\hline
\end{tabular}

Tablo 14. RFM Değerinin Yıl Bazında Hesaplaması

\begin{tabular}{|c|c|c|c|c|c|c|c|c|c|c|c|c|}
\hline ID & $\begin{array}{l}\text { Son } \\
\text { Sipariş } \\
\text { Tarihi }\end{array}$ & $\begin{array}{r}31.1 \\
\text { Kala } \\
\quad c \\
\end{array}$ & $\begin{array}{l}2.2013 \\
\text { n Süre } \\
\text { yün } \\
\end{array}$ & $\mid \begin{array}{c}\mathbf{R} \\
\text { Değeri }\end{array}$ & $\begin{array}{c}\text { Sevkiyat } \\
\text { Sayısı }\end{array}$ & $\begin{array}{c}F \\
\text { Değeri }\end{array}$ & $\begin{array}{l}\text { Satış } \\
\text { Tutarı }\end{array}$ & $\begin{array}{l}\text { Brüt Satış } \\
\text { Karı (BSK) }\end{array}$ & \begin{tabular}{|c|} 
M1 \\
Değeri \\
Satış \\
\end{tabular} & $\begin{array}{c}\text { M2 } \\
\text { Değeri } \\
\text { BSK } \\
\end{array}$ & $\begin{array}{c}\mathrm{M} \\
\text { Değeri }\end{array}$ & $\begin{array}{l}\text { RFM- } \\
2013\end{array}$ \\
\hline 1 & \multicolumn{2}{|c|}{30.12 .201} & 1 & 20 & 116 & 20 & 529.082 & 214.597 & 15 & 15 & 30 & 70 \\
\hline 2 & \multicolumn{2}{|c|}{30.12 .2013} & 1 & 20 & 184 & 25 & 1.106 .453 & 99.193 & 20 & 15 & 35 & 80 \\
\hline 3 & \multicolumn{2}{|c|}{30.12 .2013} & 1 & 20 & 206 & 30 & 1.379 .783 & 578.213 & 25 & 25 & 50 & 100 \\
\hline 4 & \multicolumn{2}{|c|}{30.12 .2013} & 1 & 20 & 33 & 10 & 154.396 & 5.050 & 5 & 2 & 7 & 37 \\
\hline 5 & \multicolumn{2}{|c|}{26.12 .2013} & 5 & 20 & 72 & 15 & 387.275 & 163.991 & 10 & 5 & 15 & 50 \\
\hline 6 & \multicolumn{2}{|c|}{30.12 .2013} & 1 & 20 & 53 & 15 & 247.551 & 107.191 & 10 & 5 & 15 & 50 \\
\hline 7 & \multicolumn{2}{|c|}{28.12 .2013} & 3 & 20 & 8 & 10 & 38.517 & 16.772 & 1 & 1 & 2 & 32 \\
\hline 8 & \multicolumn{2}{|c|}{30.12 .2013} & 1 & 20 & 178 & 25 & 950.172 & 333.221 & 15 & 15 & 30 & 75 \\
\hline 9 & \multicolumn{2}{|c|}{30.12 .2013} & 1 & 20 & 60 & 15 & 368.628 & 156.797 & 10 & 5 & 15 & 50 \\
\hline 10 & \multicolumn{2}{|c|}{31.12 .2013} & 0 & 20 & 168 & 25 & 1.550 .997 & 715.815 & 25 & 25 & 50 & 95 \\
\hline 11 & \multicolumn{2}{|c|}{12.12 .2013} & 19 & 15 & 2 & 10 & \begin{tabular}{|l}
13.7 \\
\end{tabular} & 0 & 1 & 1 & 2 & 27 \\
\hline 12 & \multicolumn{2}{|c|}{11.12 .2013} & 20 & 15 & 32 & 10 & 156.538 & 66.029 & 5 & 2 & 7 & 32 \\
\hline 13 & \multicolumn{2}{|c|}{ 17.12.2013 } & 14 & 15 & 7 & 10 & 47.288 & 22.793 & 1 & 1 & 2 & 27 \\
\hline 14 & \multicolumn{2}{|c|}{03.12 .2013} & 28 & 15 & 1 & 10 & 5.200 & 2.479 & 1 & 1 & 2 & 27 \\
\hline 15 & \multicolumn{2}{|c|}{31.12 .2013} & 0 & 20 & 52 & 15 & 286.514 & 125.303 & 10 & 5 & 15 & 50 \\
\hline 16 & \multicolumn{2}{|c|}{ 21.08.2013 } & 132 & 2 & 142 & 20 & 1.576 .987 & 693.879 & 25 & 25 & 50 & 72 \\
\hline 17 & \multicolumn{2}{|c|}{ 27.12.2013 } & 4 & 20 & 112 & 20 & 459.646 & 197.354 & 10 & 5 & 15 & 55 \\
\hline
\end{tabular}


İşletmenin her bir müşterisine ilişkin RFM değerleri yıl bazında hesaplandıktan sonra, yılların RFM değerlerinin ortalaması hesaplanır. Hesaplanan ortalama RFM değerleri 1 ile 5 arasında puanlama ataması gerçekleştirilir. Böylece 56 müşterinin yıllara göre dağııımı ve ortalamasına bağlı RFM değeri Tablo 15'de verilmektedir. RFM değerleri, Excel'in Veri Çözümleme fonksiyonu aracılığıyla çizilen histograma dayalı olarak 1 ile 5 arasında tespit edilmiştir. Bu dağılım şöyledir:

\begin{tabular}{|lcc|}
\hline RFM & & RFM Değeri \\
\hline 0,00 & 30,90 & $\mathbf{1}$ \\
\hline 31,00 & 44,90 & $\mathbf{2}$ \\
\hline 45,00 & 52,49 & $\mathbf{3}$ \\
\hline 52,50 & 71,49 & $\mathbf{4}$ \\
\hline 72,50 & 100,00 & $\mathbf{5}$ \\
\hline
\end{tabular}

Tablo 15. RFM Değerinin Tespit Edilmesi

\begin{tabular}{|c|c|c|c|c|c|}
\hline ID & RFM-2013 & RFM-2014 & RFM-2015 & $\begin{array}{c}\text { RFM } \\
\text { (Ortalama) }\end{array}$ & $\begin{array}{c}\text { RFM } \\
\text { Değeri }\end{array}$ \\
\hline 1 & 70 & 60 & 60 & 63 & 4 \\
\hline 2 & 80 & 70 & 90 & 80 & 5 \\
\hline 3 & 100 & 95 & 90 & 95 & 5 \\
\hline 4 & 37 & 14 & 27 & 26 & 1 \\
\hline 5 & 50 & 70 & 60 & 60 & 4 \\
\hline 6 & 50 & 50 & 55 & 52 & 3 \\
\hline 7 & 32 & 22 & 22 & 25 & 1 \\
\hline 8 & 75 & 85 & 90 & 83 & 5 \\
\hline 9 & 50 & 45 & 45 & 47 & 3 \\
\hline 10 & 95 & 50 & 50 & 65 & 4 \\
\hline 11 & 27 & 70 & 50 & 49 & 3 \\
\hline 12 & 32 & 50 & 45 & 42 & 2 \\
\hline
\end{tabular}

(A) İşletmesinin müşterilerine yönelik yaptı̆̆ RFM analizi ile MYBD sonuçları birlikte değerlendirilebilir. RFM analizi ile en son, en sık ve en fazla harcamayı yapan müşteriler, en değerli müşteri olarak nitelendirilmektedir. Bu durumda değerli müşterilerin derecelendirilmesi 5'den 1'e doğru ifade edilmektedir. Bu müşteri bölümlerinin gelecek dönemlerde de aynı davranışları sergileyebileceği ve müşterilerin kârııık eğiliminin bunu yansıtacağı tahmin edilmektedir. MYBD ise satın alma sıklığı analizi ve müşteri odaklı iletişim stratejilerini de temel olarak alınmaktadır. MYBD'ne göre iyi müşteriler 7'den 1'e doğru derecelendirilmektedir. Şu anki müşteri ilişkileri sonucunda elde edilen kârın, gelecekte devam edeceği beklentisi MYBD ile ölçülmeye çalışılmaktadır. Tablo 16'da müşterilerin hem RFM hem de MYBD değerleri gösterilmektedir. RFM değeri 1 olan müşterilerin genellikle MYBD 1, 2 ve 3 olurken, RFM değeri 5 olan müşterilerin ise genellikle MYBD 5,6, ve 7 olduğu tespit edilmektedir. Bu kurala uymayan 8, 17, 20 gibi müşterilere ilişkin pazarlama departmanı görüşleri de göz önünde bulundurularak yeniden değerlendirilebilir.

İşletmenin müşterileri; sadık, aktif, küskün, pasif ve yeni müşteriler gibi 5 grupta ele alınabilir. Sadık müşteriler; aldıkları hizmete göre daha az maliyete katlanır, diğer müşterilerden daha fazla ödeme yapar ve ağızdan ağza çok daha fazla müşteri çeker ve böylece çevre ile olan ilişkilerde işletmeye olumlu katkılar sağlar. Sadık müşteriler işletme için değerli olduklarının farkındadır ve yüksek kaliteli hizmetlere daha düşük fiyatlarla ulaşmaya layık olduklarına inanırlar. Bu nedenle işletmenin özellikle sadık ve aktif müşteri grubuna önem vermesi gerekmektedir. Ancak işletmeler küskün ve pasif grupları da piramidin bir üst basamağına taşıma 
yönünde çalışmalar yapması gerekmektedir. Piramidin müşteri basamaklarının oluşturulmasında en önemli ölçülerden birisi müşteri yaşam boyu değeridir.

Tablo 16. RFM ve MYBD Karşılaştırmalı Analiz

\begin{tabular}{|c|c|c|}
\hline RFM & ID & MYBD \\
\hline \multirow{10}{*}{1} & 4 & 1 \\
\hline & 7 & 1 \\
\hline & 14 & 1 \\
\hline & 22 & 1 \\
\hline & 25 & 1 \\
\hline & 28 & 2 \\
\hline & 30 & 2 \\
\hline & 34 & 1 \\
\hline & 37 & 1 \\
\hline & 44 & 2 \\
\hline \multirow{8}{*}{2} & 12 & 1 \\
\hline & 15 & 1 \\
\hline & 16 & 1 \\
\hline & 19 & 1 \\
\hline & 29 & 3 \\
\hline & 46 & 5 \\
\hline & 49 & 2 \\
\hline & 52 & 2 \\
\hline \multirow{9}{*}{3} & 6 & 2 \\
\hline & 9 & 2 \\
\hline & 11 & 3 \\
\hline & 13 & 2 \\
\hline & 24 & 1 \\
\hline & 27 & 1 \\
\hline & 42 & 3 \\
\hline & 45 & 3 \\
\hline & 56 & 4 \\
\hline
\end{tabular}

\begin{tabular}{|c|c|c|}
\hline RFM & ID & MYBD \\
\hline \multirow{16}{*}{4} & 1 & 2 \\
\hline & 5 & 2 \\
\hline & 10 & 5 \\
\hline & 18 & 5 \\
\hline & 21 & 2 \\
\hline & 26 & 3 \\
\hline & 31 & 5 \\
\hline & 35 & 5 \\
\hline & 36 & 4 \\
\hline & 39 & 4 \\
\hline & 40 & 7 \\
\hline & 41 & 7 \\
\hline & 43 & 5 \\
\hline & 51 & 5 \\
\hline & 54 & 4 \\
\hline & 55 & 5 \\
\hline
\end{tabular}

\begin{tabular}{|c|c|c|}
\hline RFM & ID & MYBD \\
\hline \multirow{13}{*}{5} & 2 & 4 \\
\hline & 3 & 4 \\
\hline & 8 & 3 \\
\hline & 17 & 3 \\
\hline & 20 & 3 \\
\hline & 23 & 4 \\
\hline & 32 & 6 \\
\hline & 33 & 7 \\
\hline & 38 & 6 \\
\hline & 47 & 6 \\
\hline & 48 & 7 \\
\hline & 50 & 5 \\
\hline & 53 & 6 \\
\hline
\end{tabular}

Müşteri yaşam boyu değerinin işletmelere sağlayacağı faydaları şöyle özetlenebilir:

- Müşteriyi elde tutmaya odaklanma,

- Daha üst düzeyde mal/hizmet yararları sunma,

- Uzun dönemli vizyonu izleme,

- Örnek olabilecek (exemplary) müşteri hizmetleri üzerinde durma,

- Müşteri bağlantılarını öngörme,

- Bütünüyle istenen kaliteye ulaşma,

- Artan satın almalar,

- Azalan maliyetler,

- Kulaktan kulağa iletişimle bedava reklam,

- Çalışanların elde tutulması,

- Müşterinin yaşam boyu değeri, 
- Kararlarında daha fazla etkinliğe ulaşmak,

- Bilgi işleme görevini azaltmak,

- Kararlarında daha fazla bilişsel uyuma ulaşmak,

- Gelecekteki satın alma tercihleriyle bütünleştirilen riski en aza indirmektir.

\section{Tartışma ve Sonuç}

Türkiye'de en önemli sorunlardan birisi işletmelerin üretim ve satış odaklı olarak faaliyetlerini sürdürmeye çalışmalarıdır. Bu nedenle işletmelerde, müşterilerine yönelik üretilmiş bilgilere ulaşmak oldukça zordur. Müşterilere ait bilgiler pazarlama departmanının hafizasında veya gizli dosyalarda saklanmaktadır. Müşteri portföyü işletmenin toprak altındaki kayıp kenti gibidir. Üzerinde çalışma yapıldıkça işletmeyi yeni ufuklara taşıyacak niteliktedir. Müşteriye gerçek değerini somut bir şekilde ortaya çıkarabilmek için ise muhasebeye önemli bir rol düşmektedir. Bu nedenle pazarlama departmanı muhasebeye sadece parasal bilgileri vermekle yetinmemeli, aynı zamanda parasal olmayan bilgileri de paylaşmalıdır. Bunu gerçekleştiren araçlardan birisi de müşteri yaşam boyu değeri yöntemidir.

MYBD işletmenin müşterilerin ihtiyaçlarını ve müşteri veri analizini kapsamlı biçimde yönetmesine, mevcut ve olası müşteriler için hedefler belirlemesine ve müşteri gruplarına yönelik özel stratejiler geliştirmesine olanak sağlamaktadır. Kısaca işletmenin karar alma noktasına ışık tutmaktadır. Örneğin, işletme müşterilerini sadık, aktif, küskün, pasif ve yeni müşteriler gibi 5 gruba ayırabilir. Bunlardan sadık müşteriler, işletmeden kesintisiz mal satn alan müşterilerdir. Aktif müşteriler, en az son iki yıl üst üste mal satın alışı gerçekleştiren müşterilerdir. Küskün müşteriler ise, üç yıllık süreç içinde eski müşteri olmalarına rağmen sadece bir yıl süresince satın alma faaliyetinde bulunmuş olan müşterilerdir. Pasif müşteriler, işletmenin müşteri olmasına rağmen hiçbir şekilde satın alma faaliyetinde bulunmayan müşterilerdir. Son olarak yeni müşteriler ise, son dönemde işletmenin müşteri portföyüne giren müşterileri kapsamaktadır. Her işletme için müşteri portföyü farklı şekillerde gruplandırılabilir.

Çalışmada (A) İşletmesinin son üç yılına ilişkin gerçek verileri incelenmiştir. MYBD ve RFM analizi için gerekli olan; "sipariş tarihi", "sevkiyat sayısı", "müşteri ömrü", "net satı̧̧ tutarı", "satı̧̧ların maliyeti", "brüt satış kârı" ve "değişken pazarlama gideri" verilerinden yararlanılmıştır. Satışların maliyeti değişken maliyetlerden oluşmaktadır. İşletmeden alınan veriler üzerinden MYBD modellerinden öne çıkan modeller (Gupta-Lehmann, Jain-Singh, Bruhn) ve RFM analizi yaklaşımı için hesaplamalar gerçekleştirilmiştir. MYBD modellerinin üstün ve zayıf yönleri bir potada eritebilmek için bulunan değerlerin ortalaması alınmıştır ve MYBD puanlamaya tabi tutulmuştur. Benzer şekilde RFM değerleri de puanlamaya tutularak, MYBD puanları ile karşılaştırılmıştır. (A) İşletmesine yönelik bir müşteri bölümlemesi yapılabilmiştir. Böylece işletmenin mevcut müşterilerini analiz etmesine, yeni stratejiler geliştirmesine, tutundurma faaliyetlerini güncellemelere gitmesine olanak sağlanmış olacaktır.

Çalışmanın en önemli sınırlılıkları müşteri ömrü boyunca gerçekleştirdiği tüm faaliyetlerin görülememesidir. Bu nedenle konuyla ilgili gelecekte yapılacak çalışmalarda; müşteri ömrünü kapsayacak gerçek veri seti üzerinde çalışılması ve sonuçların müşterilere ilişkin pazarlama departmanı görüşlerinin alınması ve bu iki sonucun birbiriyle karşılaştırılarak müşteri gruplarının oluşturulması önerilmektedir.

\section{Kaynaklar}

Alagöz Başaran, S. (2003). Bilişim teknolojilerinin müşteri iliş̧kileri yönetimi (CRM) üzerine etkileri ve bankacılık sektöründe uygulama. Selçuk Üniversitesi Sosyal Bilimler Enstitüsü, Yayınlanmamış Doktora Tezi, Konya.

Berger, P., \& Nasr, N. (1998). Customer lifetime value: Marketing models and applications. Journal of Interactive Marketing, 12(1), pp.17-29.

Berry, M. J. A., \& Linoff, G.S. (2004). Data mining techniques for marketing, sales and CRM. (2nd Ed). Indianapolis: Wiley Publishing Inc. 
Cannon, J. P., \& Narayandas N. (2000). Relationship marketing and key account management. In: Handbook of Relationship Marketing. Ed.: Jagdish N. Sheth, Atul Parvatiyar, Sage Publications Inc.

Ceran, Y., \& Inal, M. E. (2004). Maliyet bilgileri temeline dayalı pazarlama kararları için pazarlama muhasebesi. Erciyes Üniversitesi Iktisadi ve Idari Bilimler Fakültesi Dergisi, 22, pp. 63-83.

Edvardsson, B., Thomasson, B., \& Qvretveit, J. (1994). Quality of service making it really work. UK: Mc Graw-Hill.

Ersoy, N. F. (2015). B2B/endüstriyel müşteri davranışları ve satın alma merkezi analizi. Ankara: Detay Yayıncılık.

Gupta, D., Hanssens, D., Hardie, B., Kahn, W., Kumar, V., Lin, N., \& Ravishanker, N. (2006). Modeling customer lifetime value. Journal of Service Research, 9(2), pp.139-155.

Gupta, S., \& Lehmann, D. R. (2003). Customers as assets. Journal of Interactive Marketing, 17(1), pp.9-24.

Gurau, C., \& Ranchhod, A. (2002). How to calculate the value of a customer measuring customer satisfaction: A platform for calculating predicting and increasing customer profitability. Journal of Targeting. Measurement And Analysis For Marketing, 10(3), pp.203-219.

Hızıroğlu, A., \& Şengül, S. (2012). İki müşteri yaşam boyu değeri modelinin müşteri segmentasyonu açısından incelenmesi. Yöneylem Araştırması ve Endüstri Mühendisliği Ulusal Kongresi-YAEM, 32,ss.1-10. http://Kutuphane.Dogus.Edu.Tr/Mvt/Pdf.Php?Pdf= 0014730\&Lng=0 (Erişim Tarihi: 08.06.2016)

Hwang, H., Jung, T., \& Euiho, S. (2004). An LTV model and customer segmentation based on customer value: A case study on the wireless telecommunication industry. Expert Systems with Applications, 26, pp.181-188

İslamoğlu A. H. (2009). Sosyal bilimlerde araştırma yöntemleri: SPSS uygulamalı. İstanbul: Beta Yayıncılık.

Jain, D., \& Singh, S. S. (2002). Customer lifetime value research in marketing: A review and future directions. Journal of Interactive Marketing, 16, pp.34-46.

Keiningham, T., Bejou, D., \& Aksoy, L. (2006). Customer lifetime value: Reshaping the way we manage to maximize profits. New York: The Haworth Press.

Koch, R. (1999). 80-20 ilkesi. İstanbul: Varlık Yayınları.

Kırım, A. (2001). Strateji ve bire-bir pazarlama CRM. Sistem Yayıncılık.

Kumar V., \& Shah D. (2004). Building and sustaining profitable customer loyalty for the 21st century. Journal of Retailing, 80(4), pp.317-329.

Kumar, V., Ramani, G., \& Bohling, T. (2004). Customer lifetime value approaches and best practice applications. Journal of Interactive Marketing, 18(3), pp.60-72.

Kumar V. (2008). Customer lifetime value: The path to profitability. Foundations and Trends(r) Marketing. 2(1), pp.1-96.

Kumar V., \& Rajan B. (2009). Profitable customer management: Measuring and maximizing customer lifetime value. Management Accounting Quaterly, 10:3.

Millman, T., \& Wilson, K. (1995). From key account selling to key account management. Journal of Marketing Practice, $1(1)$, pp.9-21.

Özdemir, Ö. P. (2007). Anahtar müşteri yönetimi ve büyük ölçekli türk işletmelerinin anahtar müşteri seçimi kriterleri. Finans Politik \& Ekonomik Yorumlar, 44(512), ss.28-42.

Özdemir E., \& Kaygusuz, S.Y. (2009). Müşteri kârlılık analizi: Faaliyet tabanlı maliyetleme ile ölçümü ve pazarlama kararlarında kullanımı. İş, Güç, Endüstri ilişskileri ve Insan Kaynakları Dergisi, 11(3), ss.87-112.

Özkul, E. (2006). Müşteri ilişkileri yönetimi ve otel işletmelerinde uygulanması. Dokuz Eylül Üniversitesi, Yayınlanmamış Doktora Tezi, İzmir.

Peelen, E., \& Beltman, R. (2013). Customer relationship management. Harlow, United Kingdom: Pearson.

Persson, A., \& Ryals, L.(2010). Customer assets and customer equity: Management and measurement issues. Marketing Theory, 10(4), pp.417-436.

Stahl, H., Matzler, K., \& Hinterhuber, H. (2003). Linking customer lifetime value with shareholder value. Industrial Marketing Management, 32,pp.267-279.

Schneider, G., \& Sağlam, D. (2007). Müşteri yaşam boyu değeri hesaplama modelleri ve model değişkenlerine genel bir bakış. Pazarlama Dünyası, 5, ss.32-38.

Selvi, M. S. (2007). Iilişkisel pazarlama stratejiler ve teknikler. (1. Basım) Ankara: Detay Yayıncılık.

Tarhan, O. (2016). Yapı malzemeleri sektöründeki bir işletmenin yetkili satıcılarının rfm analizi ve müşteri yaşam boyu değeri kullanılarak kümelenmesi. Anadolu Üniversitesi Sosyal Bilimler Enstitüsü, Yayımlanmamış Tezsiz Yüksek Lisans Dönem Projesi, Eskişehir. 
Tekel, S. (2006). Sigortacılıkta müşteri ilişkileri yönetimi yaklaşımının önemi ve bir branş uygulaması. Marmara Üniversitesi Sosyal Bilimler Enstitüsü, Yayınlanmamış Yüksek Lisans Tezi, İstanbul.

Yapraklı, T. Ş., \& Keser, E. (2008). Müşteri yaşam boyu değerinin analizi: Bir saha araştırması. Atatürk Üniversitesi Sosyal Bilimler Dergisi, 12(2), ss.483-503.

Zinkhan, G. M., \& Verbrugge, J. A. (2000). The marketing/ finance interface: Two divergent and complementary views of the firm. Journal of Business Research 50(2), pp.143-148.

$\mathrm{http}: / /$ bekerman.com/blog/wp-content/uploads/2014/09/DIYRFM.pdf (Erişim Tarihi: 08.06.2016)] 